\title{
Archaeological Research at the Wilson-Durham-Chandler Site
}

Molly Morgan

Center for Archaeological Studies

Follow this and additional works at: https://scholarworks.sfasu.edu/ita

Part of the American Material Culture Commons, Archaeological Anthropology Commons, Environmental Studies Commons, Other American Studies Commons, Other Arts and Humanities Commons, Other History of Art, Architecture, and Archaeology Commons, and the United States History Commons

Tell us how this article helped you.

This Article is brought to you for free and open access by the Center for Regional Heritage Research at SFA ScholarWorks. It has been accepted for inclusion in Index of Texas Archaeology: Open Access Gray Literature from the Lone Star State by an authorized editor of SFA ScholarWorks. For more information, please contact cdsscholarworks@sfasu.edu. 


\section{Archaeological Research at the Wilson-Durham-Chandler Site}

Creative Commons License

(c) (i) (8)

This work is licensed under a Creative Commons Attribution-NonCommercial 4.0 International License 


\section{Archaeological Research at the}

\section{Wilson-Durham-Chandler Site}
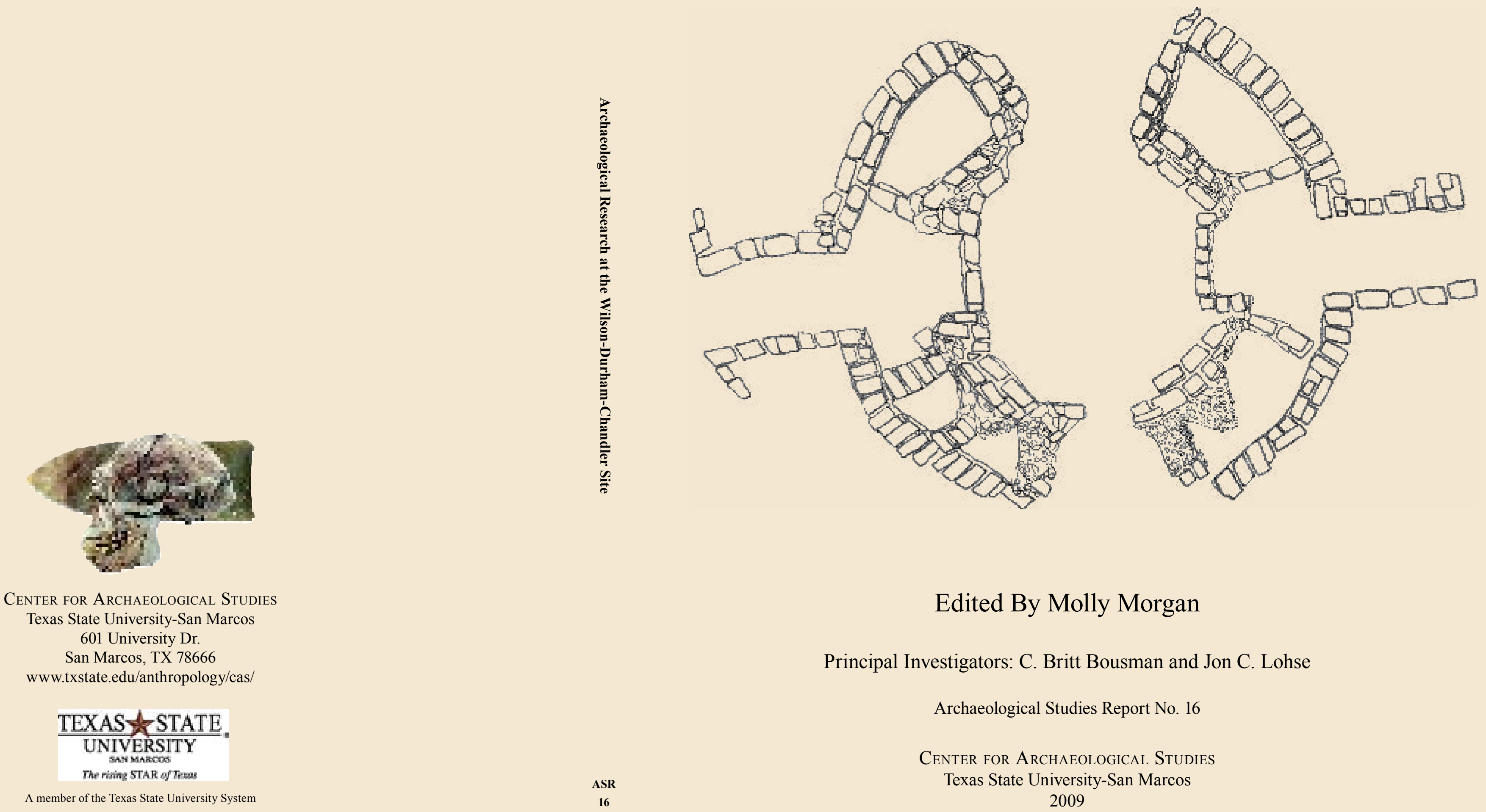

Edited By Molly Morgan

Principal Investigators: C. Britt Bousman and Jon C. Lohse

Archaeological Studies Report No. 16

Center for Archaeological Studies Texas State University-San Marcos 


\section{Archaeological Research at the Wilson-Durham-Chandler Site}

edited by

Molly Morgan

Principal Investigators:

C. Britt Bousman and Jon C. Lohse

Archaeological Studies Report No. 16

Center for Archaeological Studies

Texas State University-San Marcos

2009 
The following information is provided in accordance with the General Rules of Practice and Procedures, Title 13, Chapter 26, Texas Administrative Code:

1. Type of investigation: Documentation and conservation of cultural resources.

2. Project name: Archaeological Research at the Wilson-Durham-Chandler Site

3. County: Guadalupe

4. Principal Investigators: C. Britt Bousman and Jon C. Lohse

5. Name and location of sponsoring agency: Wilson Pottery Foundation, P.O. Box 681802, San

Antonio, TX, 78268

6. Published by the Center for Archaeological Studies, Texas State University-San Marcos, 601 University

Drive, San Marcos, Texas, 78666-4616 (2009)

Texas State University-San Marcos is a member of the Texas State University System Copyright (C) 2009 by the Center for Archaeological Studies at Texas State University-San Marcos

All rights reserved.

No part of this book may be reproduced or utilized in any form or by any means, electronic or mechanical, including photocopying, recording,

or by any information storage and retrieval system without permission in writing.

For further information on this and other publications by

the Center for Archaeological Studies, please contact:

Center for Archaeological Studies

Texas State University-San Marcos

601 University Drive

San Marcos, TX 78666-4616

www.txstate.edu/anthropology/cas/

Editor: Brooke S. Boyer

Cover Photograph: Plan drawing of the beehive kiln, 2009.

Printed in the United States of America

by

Texas State University Print \& Mail Services, Texas State University-San Marcos 


\section{Abstract}

The Wilson-Durham-Chandler site, 41GU4, is located near the old community of Capote, on State Highway 466, east of Seguin, in Guadalupe County, Texas. It is one of three archaeological sites that hold the remains of a pottery manufacturing business operated by members of the Wilson family before and following the Civil War. The first of these sites was owned by the slave holder John McKamie Wilson, and was managed by several of his slaves from around 1857 to 1869 . After emancipation, those slaves became some of the earliest African American entrepreneurs in Texas. Hiram Wilson established and ran the H. Wilson and Company pottery business, with the aid of James, Wallace, George, and Andrew Wilson, from around 1869 to 1884. James and Wallace Wilson later bought into the Wilson-Durham-Chandler pottery manufacturing business, which had opened in 1869, and worked as partners with Marion Durham and John Chandler until that operation closed in 1903.

Work conducted by the Center for Archaeological Studies, under contract with the Wilson Pottery Foundation, and sponsored by that foundation with a grant from the Texas Historical Commission, was undertaken in 2007-2009 to document and conserve the remains of the Wilson-Durham-Chandler site, protecting the location of important socioeconomic transitions following the Civil War. Today, these material remains, along with other significant locations in Seguin including the other Wilson sites, the Capote community church, cemetery, and schoolhouse, and the Wilson Pottery Museum (under construction for a future opening) all function to link members of modern society with important people and events of the past. In this way, this project has sought to fulfill archaeological goals of documentation and conservation, but also to perform a social role for archaeology in providing and protecting material remains of the past so that people today can use them to understand their origins, contemplate this country's history, and shape present-day social identity.

This report summarizes the archaeological work that has been conducted at the WilsonDurham-Chandler site. It begins with a brief introductory chapter that outlines the history of the Wilson family and the establishment of the three Wilson pottery manufacturing locations. This report also includes information gained through interviews with Richard Kinz regarding his excavations at the Wilson-Durham-Chandler site, a chapter on the subsequent GPR survey conducted by the Texas Historical Commission, as well as a chapter describing the documentation and preservation work conducted by CAS. Lastly, the conclusion chapter focuses on the unique aspects of this project and the significance of the Wilson sites, suggesting a social role for archaeology. 


\section{Table of Contents}

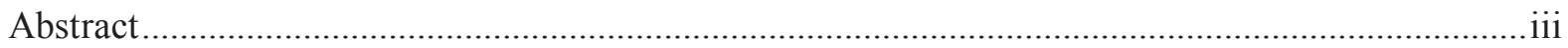

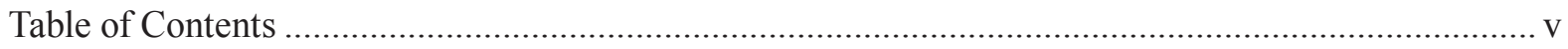

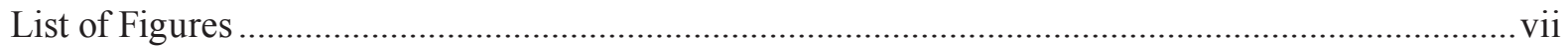

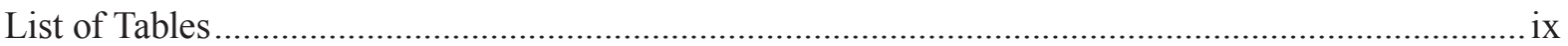

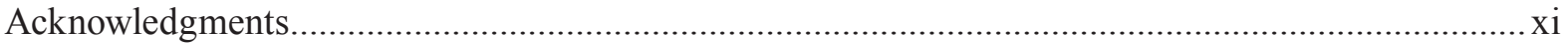

Chapter 1. Introduction: The Wilson Family and the History of the Wilson Pottery Sites ............. 13 Molly Morgan

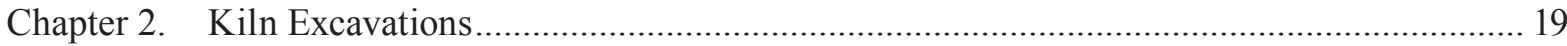

Richard Kinz and Molly Morgan

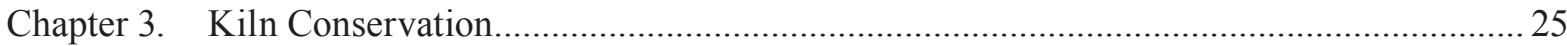

Molly Morgan and Jon C. Lohse

Chapter 4. Ground Penetrating Radar Survey ........................................................................... 31 Tiffany Osburn

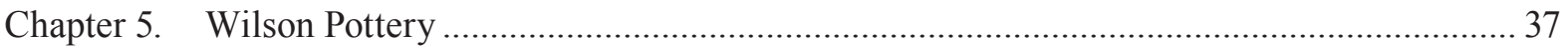
Molly Morgan

Chapter 6. Conclusions: A Social Role for Archaeology and the Future of the Wilson Pottery Sites

Molly Morgan

References Cited 


\section{List OF Figures}

1-1. Map of the Capote area showing the locations of the three Wilson Pottery Sites, by Jon C.

Lohse, CAS Director, 2009.

1-2. Manufacturer's mark indicating that this pot was produced at the Hiram Wilson Pottery Site. 15

1-3. Portrait of Hiram Wilson. Image used with permission of the Institute of Texas Cultures ...... 16

2-1. Map of the Wilson-Durham-Chandler site showing locations of the test excavations conducted in 1996, by Jon C. Lohse, CAS Director, 2009 ................................................................. 20

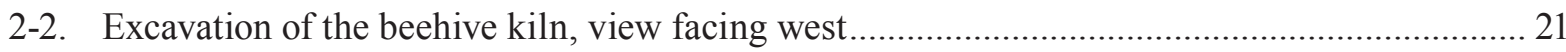

2-3. Model of the Beehive Kiln by artist Joe Pirog.......................................................................... 21

2-4. Excavation of the western wall of the groundhog kiln ........................................................... 22

2-5. Hand-made bricks from the groundhog kiln, demonstrating glazed inside edges where they functioned as part of the architecture on the interior wall ................................................ 23

3-1. The collection of pottery sherds from sorting tables at the Wilson-Durham-Chandler site ...... 25

3-2. Photo of the beehive kiln, taken from the west side ............................................................... 26

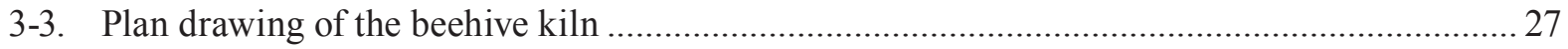

3-4. Profile drawing of the beehive kiln, facing southeast.............................................................. 27

3-5 Profile drawing of the beehive kiln, facing southwest....................................................... 28

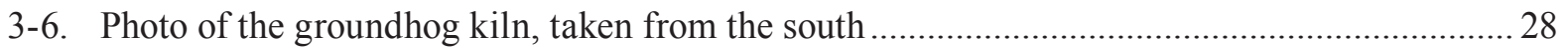

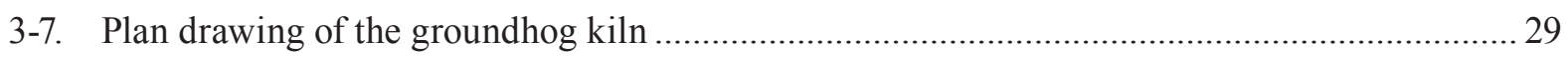

3-8. Profile drawing of the eastern wall of the groundhog kiln, from the interior ............................ 30

3-9. Profile drawing of the double chimney at the northern end of the groundhog kiln .................. 30

3-10. On August 4, 2008, Wilson Pottery Foundation members ceremonially threw the first shovels of dirt onto the beehive kiln to begin the conservation work............................................... 30

4-1. Location and orientation of GPR survey grids within the fenced area of the Wilson-Chandler-

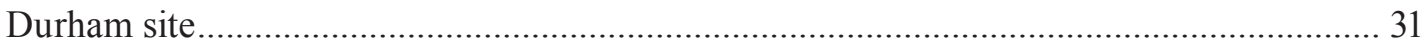

4-2. Tiffany Osburn conducting GPR survey at the Wilson-Chandler-Durham site........................ 32

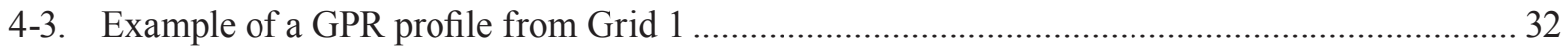




\section{List OF Figures (Continued)}

4-4. Natural stratigraphic layer appears to undulate when the antenna travels up and down over

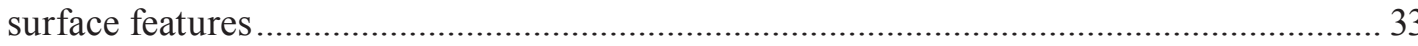

4-5. GPR amplitude slice maps of data collected over Grids 1 and 2 (grid in meters) ..................... 34

4-6. GPR amplitude slice map 5 (20-25 ns; grid in meters) showing potential features.................. 35

5-1. Schematic drawing of a groundhog kiln, showing front firebox and entryway, interior firing

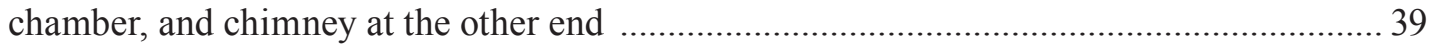

5-2. Photo of a bob (type of kiln furniture) collected from the Wilson-Durham-Chandler Pottery

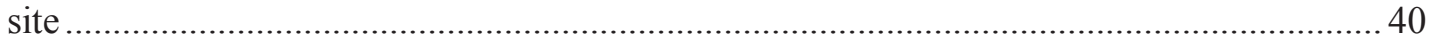

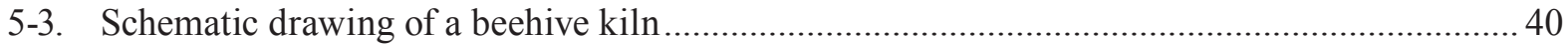




\section{List OF TABLES}

5-1. Counts of ceramic sherds collected from the groundhog kiln and beehive kiln at the WilsonDurham-Chandler site (41GU4) by the Center for Archaeological Studies 



\section{ACKNOWLedgments}

The work conducted by the Center for Archaeological Studies (CAS) at the Wilson-DurhamChandler site was made possible by several groups and individuals. First, we thank the Wilson Pottery Foundation, especially its president, LaVerne Britt, for inviting us to be a part of this wonderful project. We are honored to have engaged in this contracted work. Their sponsorship would not have been possible without the Preservation Trust Fund Grant from the Texas Historical Commission (THC) and the matching grant from the Summerlee Foundation.

Several individuals participated in the collection, cleaning, and curation of pottery sherds, as well as site clean-up, kiln conservation, site maintenance, and survey. Thanks go to many members of the Wilson Pottery Foundation that came out to contribute their labor as we worked at the site. Several CAS employees also played fundamental roles in this work, including Spencer LeDoux, Julian A. (Drew) Sitters, and David Yelacic. Drew Sitters and David Yelacic assisted Jon Lohse in site mapping. Michael Morgan also volunteered during the backfilling conservation work. Back at the CAS laboratory facility, Brooke Boyer cleaned, sorted, and counted all 16,007 pottery sherds that we collected from the site. Brooke also edited and formatted this report. Lastly, Tiffany Osburn, of the THC, volunteered her time and expertise to conduct a ground-penetrating radar survey and wrote up the results for the fourth chapter of this report. This work could not have been accomplished without the specialized tasks performed by these individuals.

Lastly, many people were eager to share their knowledge of the Wilson family, Wilson pottery sites, and Texas stoneware as information was gathered for this publication. Richard Kinz, with the aid of Judy and Floyd McKee, patiently recounted his activities at the Wilson-Durham-Chandler site for the chapter on kiln excavation. George Russell invited CAS employees to his home in Huntsville, Texas, to view his substantial collection of Wilson pottery pieces. Anne Fox allowed the collections and notes on Wilson pottery by Georgeanna Greer to be viewed at the Center for Archaeological Research at the University of Texas, San Antonio. Lastly, Jeff Durst provided information on the involvement of the THC in the conservation of the Wilson sites and the future plans for the Wilson Pottery Museum. He also offered useful comments on the final chapter. Much gratitude goes to all of the individuals that contributed in some way to the collection of information presented in the pages of this report. 



\section{Chapter 1}

\section{INTRODUCTION: \\ The Wilson Family and the History of the Wilson Pottery Sites}

Molly Morgan

The Center for Archaeological Studies (CAS) at Texas State University investigated the WilsonDurham-Chandler Pottery site (site number 41GU4) in 2007-2008 under a contract with the Wilson Pottery Foundation. The objectives of this work included the documentation and conservation of the remains of a pottery manufacturing business, which was in operation from 1869 to 1903 . The business was originally owned by Marion Durham and John Chandler. James and Wallace Wilson also became owners and partners sometime after 1884. It is probable that the former slaves Hiram, James, and Andrew Wilson also worked at this site, before and/or after Hiram operated his own independent pottery business. The Wilson Pottery sites are significant in that they represent some of the earliest African American businesses in the state of Texas.

This first chapter of this report introduces the historic Wilson Pottery sites by recounting the story of the founding of these potteries by members of the Wilson family, including slave owner John McKamie Wilson, Jr. and the slaves and subsequent freedmen Hiram, James, Wallace, George, and Andrew Wilson (in many parts of the south, slaves took the last names of their former owners upon gaining freedom).

In the book, In Praise of Hiram Wilson, LaVerne Lewis Britt (2005) tells the story of the life of Hiram Wilson, her great-great-grandfather. Hiram was born under slavery in Mecklinburg County, North Carolina in 1836. Details of his early life before arriving in Texas with the family of John McKamie Wilson, Jr. in 1856 are largely unknown. More is known about the wealthy slave owner John McKamie Wilson, who practiced law in Burke County, North Carolina. Around 1846-47 he moved with his family and slaves to Fulton County, Missouri, where he worked as a Presbyterian Minister and was instrumental in building a seminary and school. Finally, in 1856 Wilson and his group entered Texas, apparently to continue maintaining slaves while northern states were challenging the practice. While in Texas, Wilson supported the Southern cause in the Civil War by sending two of his sons to fight for the Confederacy (Brackner 1981).

In Texas, John McKamie Wilson set up his household in Seguin, Guadalupe County. His works in the Seguin community included minister of the Presbyterian Church, headmaster of the female academy of Guadalupe College, and eventually the owner of a stoneware pottery business. These roles are highlighted in A Handbook of Texas Online article by Jean Andrews (2008). In the days before refrigeration or even the delivery of blocks of ice, utilitarian stoneware pottery was in great demand to store and conserve perishable food items. Having spent time in the Edgefield District of the Carolinas, Wilson certainly knew the economic potential and some degree of the technology behind pottery manufacturing. Wilson has been quoted as stating, "From the high price of stoneware and the demand for it, I felt that the pottery business 
would be profitable and a source of convenience and pecuniary advantage to the country" (Blake, Johnson, and Kinz 1999). He soon set up his own Guadalupe Pottery business in the Capote Hills, an area rich in raw clay resources. Guadalupe Pottery was staffed and maintained by Wilson slaves who had either learned how to make pottery in the Carolinas or Missouri, or were taught pottery manufacturing by John McKamie Wilson, Jr. or by hired specialists in Texas, perhaps including Isaac Suttles, Marion Durham, and John Chandler.

Guadalupe Pottery (41GU6), a utilitarian stoneware pottery manufacture site is the first of three sites that today still reveal the remains of Wilson Pottery production (Figure 1-1). John McKamie Wilson began the tradition of producing ceramic containers for food storage at this locale. A magnetometry survey of this site, conducted as part of a masters' thesis by Elmer Joe Brackner, Jr. (1981) revealed the remains of one oblong groundhog kiln at the site, as well as

FIGURE 1-1. REDACTED

Figure 1-1. Map of the Capote area showing the locations of the three Wilson Pottery Sites, by Jon C. Lohse, CAS Director, 2009. a metal anomaly that may be part of the pug mill used to grind the clay. A large waster pile was also visible on the surface of the site at the time of Brackner's study. Ceramics at this site were made with the alkaline and the salt glaze surface treatments. This first Wilson Pottery business lasted until 1869. Wilson Pottery production continued in later years at two other locales.

The Wilson-Durham-Chandler Pottery Site (41GU4) was the second location of Wilson pottery production. Marion Durham, a white man, and John Chandler, an African American, were potters from South Carolina that moved to Texas in the late 1860s (Brackner 1981). They purchased the manufacturing equipment from John McKamie Wilson when he closed his first pottery, and founded this second production site. It seems that they may have moved the pottery manufacturing business to the new locale to be closer to the raw clay resource and the road that linked Seguin to the Capote community (Brackner 1981; Greer 1985). Ex-slaves from Wilson's business also worked at this locale. It is unclear if Hiram, James, and Wallace Wilson worked at the WilsonDurham-Chandler site first, or if Hiram began the third Wilson pottery right away in 1869 . The Wilson-Durham-Chandler manufacturing locale is believed to have been in use until around 1903. According to Georgeanna Greer (n.d.a.), 1880-1900 was the height of stoneware pottery production in Texas. The material remains suggest a successful business at WilsonDurham-Chandler, with several kilns and waster piles visible on the surface. 
Following the Civil War, emancipation became a reality in Texas around 1865 . Several pottery manufacturing businesses were founded in the state during this time, and the Wilson potteries were just a few of these (Greer, n.d.a.). The Wilson slaves had become freedmen and paid workers, most of them continuing to be employed by former slave holders in and around Seguin. Hiram Wilson, however, being trained in the ceramics manufacturing technology at Guadalupe Pottery, saw the potential for the establishment of another pottery in SouthCentral Texas. With the aid of James, Wallace, George, and Andrew Wilson, they founded the H. Wilson and Company pottery business. This was a noteworthy step in the post-Civil War economic transitions in Texas. As stated by Britt, "This pottery was indeed a first. Never before had anyone of African decent ascended to the level of entrepreneurship in Texas" (2005:20). The pottery making business probably included at least one work shed with pottery wheel, a pug mill for processing clay, and a groundhog kiln.

H. Wilson and Company (41GU5) began sometime between 1869 and 1872 and was in business until 1884 (Brackner 1981). Production of pottery at this site demonstrated some innovative design characteristics. The pottery was primarily salt-glazed with brown slip on the interior. Furthermore, the handles were smaller than those previously produced and were of a horseshoe shape. Hiram Wilson also employed the use of a manufacturer's mark indicating the production locale of " $\mathrm{H}$. Wilson and Company" (Figure 1-2). Lastly, churns and jars from this site exhibited lids that fit ledges on the interior of the vessel rim (called "cavetto" rims by Georgeanna Greer), which would serve to hold the lid in place and replace the need to fasten the lids closed with cloth (Brackner 1981). The production of pottery at this site ceased sometime following Hiram's death on August 4th, 1884 (Britt 2005). Those men who had worked for Hiram, probably including James and Wallace Wilson, became partners with Durham and Chandler and worked at that pottery until it closed in 1903.

The H. Wilson and Company site exhibited one groundhog kiln, which was clearly visible on the surface until recently, and has now been destroyed by looters (Richard Kinz, personal communication 2009). This site was also the focus of the masters' thesis by Elmer Joe Brackner Jr. (1981). Brackner describes the small groundhog kiln, and states that two waster piles were visible on the surface. He describes the pottery sherds as being either treated on the surface with brown slip on the entire vessel or with brown slip on the interior and salt glaze on the exterior.

Besides his contributions to ceramic container production in post-Civil War Texas,

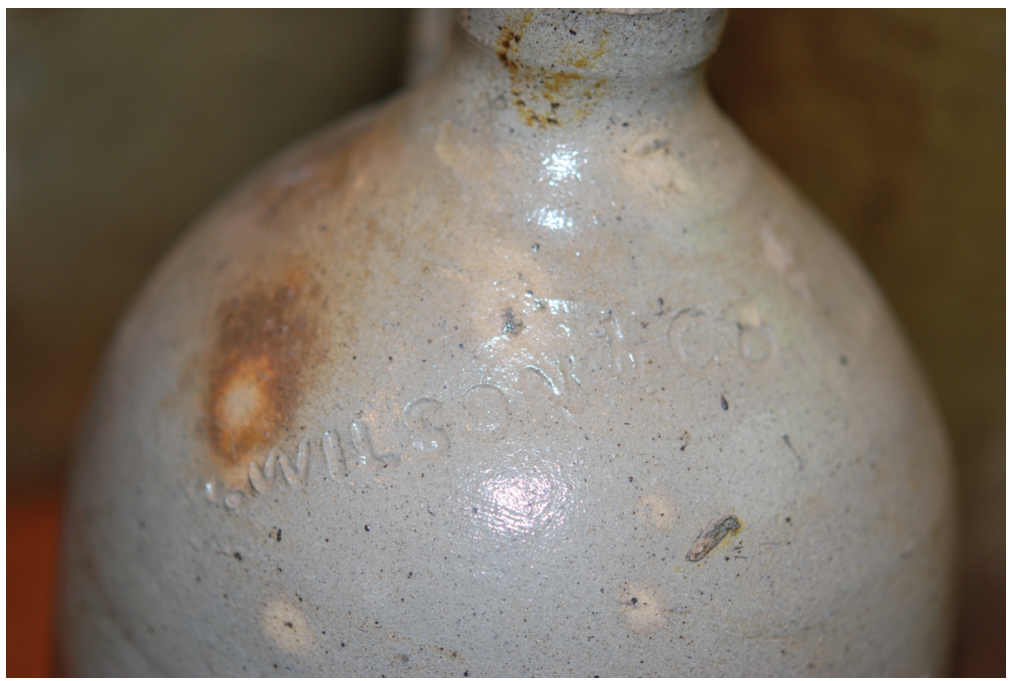

Figure 1-2. Manufacturer's mark indicating that this pot was produced at the Hiram Wilson Pottery Site. This vessel is part of the George Russell collection of Wilson Pottery. Photo taken with permission of the owner. 
Hiram Wilson also became a prominent community leader in Capote after emancipation (Figure 1-3). With the financial aid of his mentor, Reverend Leonard Isley, a Baptist Missionary, he procured most of the land that comprised Capote in separate purchases in 1872, 1876, and 1879 (Britt 2005). The first purchase was the largest, involving 600 acres, including the ten acres set aside for the schoolhouse, church, and cemetery that became the heart of the town. The rest of the land he sold in lots of forty acres to individuals bringing other freed slaves and their families to his small community.
After Capote was established as an independent African American community, inhabited mostly by freedmen that purchased small tracts of land from Hiram Wilson, he went on to achieve other accomplishments in the community and beyond. In addition to owning the pottery business, Hiram was a Baptist minister, educated at Bishop College in Marshall, and the founder of the Capote Baptist Church. He worked to bring opportunities for education to his people by working on the Guadalupe Baptist District Association for the founding of Guadalupe College. Hiram died in 1884 and his

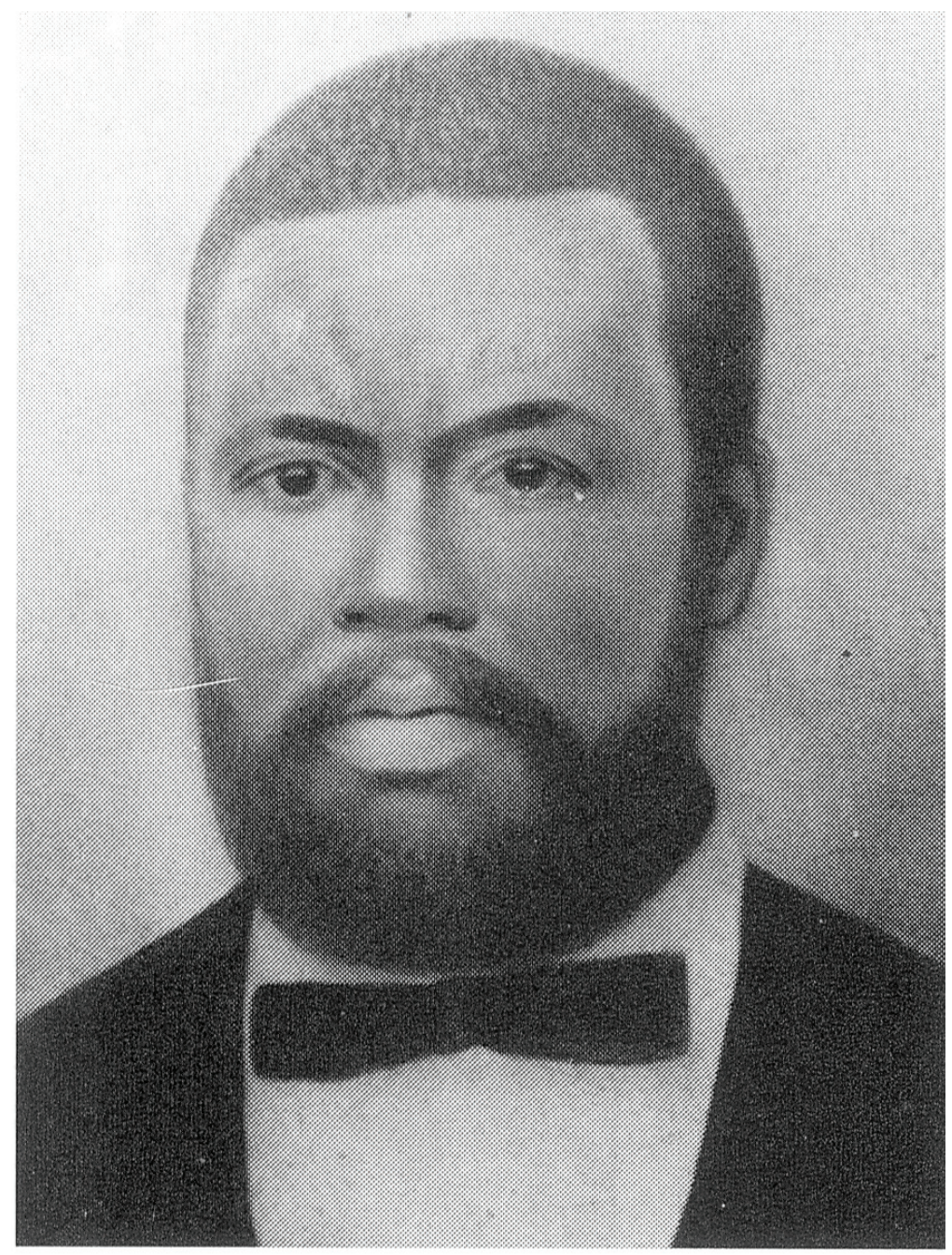

Figure 1-3. Portrait of Hiram Wilson. Image used with permission of the Institute of Texas Cultures. 
headstone is still recognizable beside the Capote Baptist Church.

The story of Hiram Wilson embodies the story of the Wilson Pottery Sites and the historical accomplishments and transitions that these archaeological remains represent. Overcoming bondage and discrimination, rising to a powerful status within the Capote community, and leaving behind the material remains of a society in transition are all significant accomplishments of this man. The example of Hiram Wilson and the sites of Wilson Pottery production have set the scene for Center for Archaeological Studies to approach three main goals of historical archaeology: to study historically disenfranchised groups, to fill the gaps in written history, and to illuminate power imbalances and document important transitions in the developing economy of the United States. In his extensive account of Wilson pottery production in the post-Civil War era, Brackner states, "The black men and women of Seguin and the rest of the South at this time are almost silent in the documentary record" (1981:60). However, the work summarized here is contributing to a growing body of information that continues to give voice to these important individuals in Texas history. 


\section{Chapter 2}

\section{Kiln ExCavations}

Richard Kinz and Molly Morgan

Richard Kinz worked as an archaeological steward of the Texas Historical Commission (THC) for Guadalupe County from around 19832000. After his work with the THC, he dedicated seven years to working at the Wilson-DurhamChandler site. Kinz performed test excavations around the visible pottery site, as well as excavations into a beehive kiln and a groundhog kiln. This chapter reports upon this work by summarizing the information gained through interviews between Molly Morgan and Richard Kinz in May 2009.

Before beginning work at the site, Kinz performed some background research on the land where the site was located, reconstructing its ownership and maintenance history. According to deed records, the original pottery manufacturing business belonging to Marion Durham and John Chandler was located on five acres, beginning at the corner of the original pottery shed. When the Capote Road was realigned, the section of land where the shed was located was destroyed and the new road was taken directly through the pottery area. The Texas Department of Transportation made a remuneration payment at the time to the landowner of the adjoining property, a man by the name of Turner. The ambiguous deed description leaves the exact location of the original five acres uncertain.

\section{Test Pit Excavations}

Kinz began work at the site by investigating the area and determining the locations of visible kilns, pottery waster piles, and a hand dug well located about one hundred feet downstream to the east, adjacent to Salt Creek. After initial reconnaissance, test pit excavations were performed to better understand buried deposits. Two test pit excavations were performed at the Wilson-Durham-Chandler Pottery site in 1996. These test pits were located toward the southwest side of the site, near Salt Creek (Figure 2-1). They were excavated as 1x1 $\mathrm{ft}$. square units.

One of the test pits, located inside of the fence that borders the site area, revealed approximately 3 feet of sand covering pottery and bricks. The bricks sat on top of clay. It is possible that this find indicates the location of the earliest work area at the site, a kiln or workshop that was initially constructed near the creek bank, but later buried when the water level in the creek rose and flooded the surrounding area.

The other test pit, located further from the center of the site, also demonstrated approximately 3 feet of sand, covering a cultural layer, with clay beneath. The terrace near the creek separates the southwestern lower sandy area that is filled with alluvial deposits from the rest of the site, which sits on the higher ground nearer to the highway. 


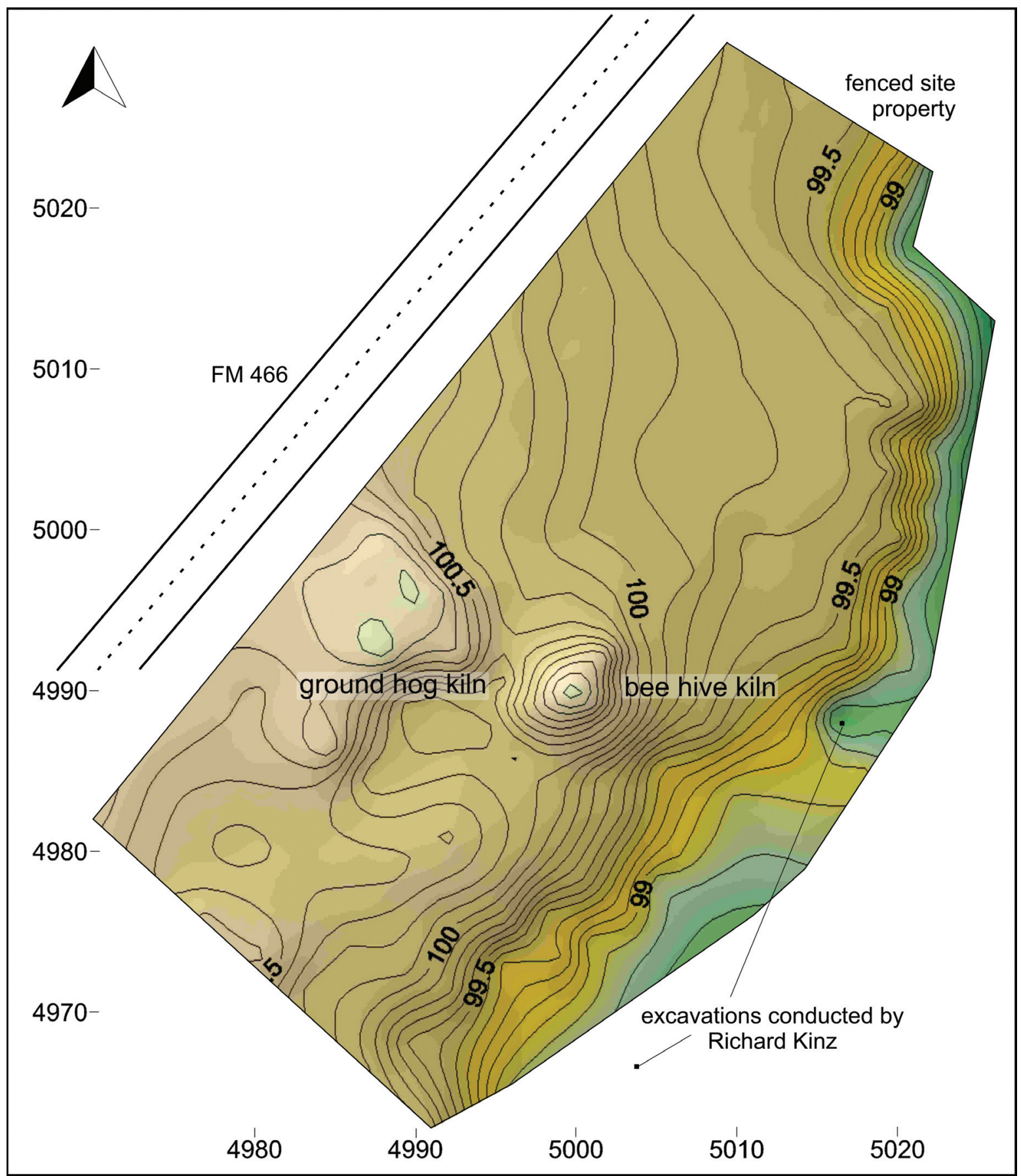

Figure 2-1. Map of the Wilson-Durham-Chandler site showing locations of the test excavations conducted in 1996, by Jon C. Lohse, CAS Director, 2009.

\section{Beehive Kiln Excavations}

Excavations at the beehive kiln were conducted around 1999-2006. These excavations uncovered the entire beehive kiln, exposing all of the walls of this feature. This kiln was clearly visible on the surface of the site before excavation. It had been looted in 1952, as reported by local area residents. The roof was entirely collapsed 
and there were several looters' holes dug into the kiln before the excavations began.

Excavators working at the Beehive Kin included Oly Schrank, Beth Langy, and Richard Kinz. The limits of the excavation were set by following the visible architecture (Figure 2-2). Kinz recognized the floor of the kiln when he reached a compact and slick surface. The bricks in the walls sat on top of this slick floor. It is not clear how the kiln worked without the usual two levels of chambers (see Chapter 5, Figure 5-3). No excavations were conducted to lower levels.

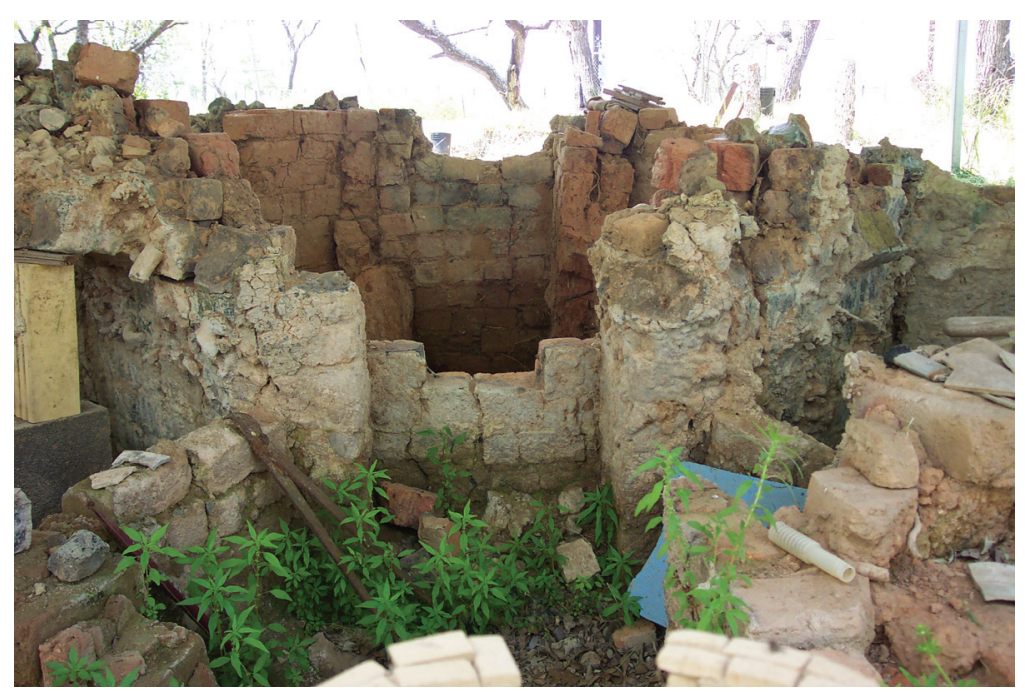

Figure 2-2. Excavation of the beehive kiln, view facing west.

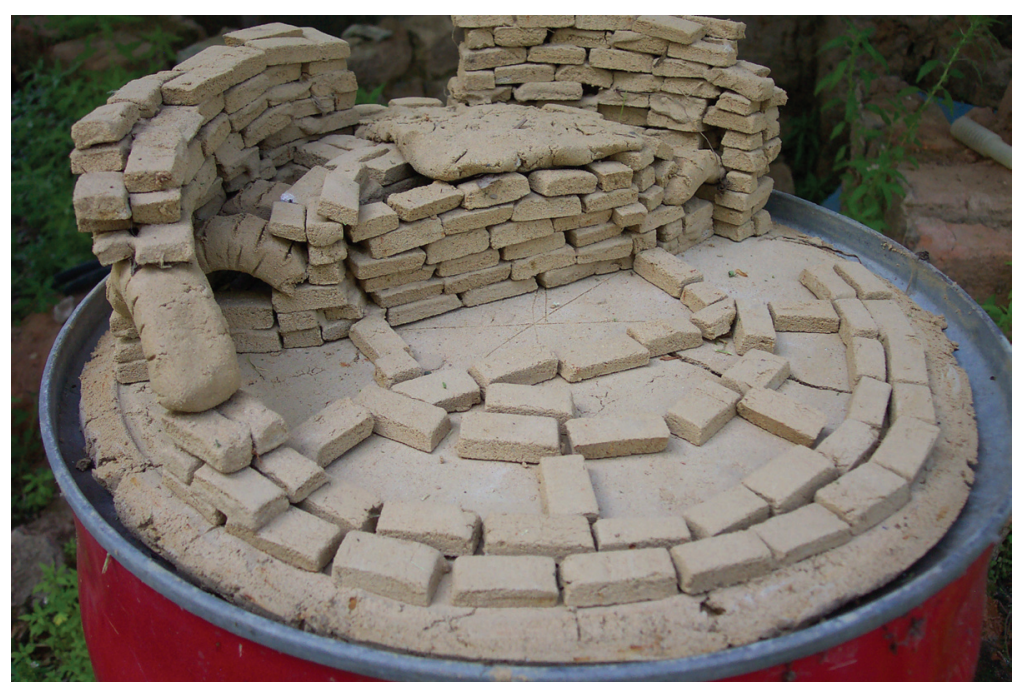

Figure 2-3. Model of the Beehive Kiln by artist Joe Pirog.
While working at the Beehive Kiln, Kinz was assisted by the artist Joe Pirog. This artist made a model of the beehive kiln, illustrating the interior architecture (Figure 2-3). He read about the Wilson Pottery Site and came to see the area for himself. Pirog was a potter interested in reconstructing Wilson Pottery, and his interest in the site caused him to purchase land in the Seguin area. He had hoped to make modern pottery in the style of utilitarian stoneware mimicking the Wilson tradition, but was not pursued by the Wilson Foundation to conduct this work. Pirog was responsible for constructing an extension of the fence that borders the site, moving it further to the east to enclose the beehive kiln area.

\section{Groundhog Kiln Excavations}

Excavations at the groundhog kiln were conducted in 2004-2006. Jon St. Clair, volunteer on the project, located this kiln by kicking up dirt above the bricks. Then the excavators opened excavations in that spot and exposed the interior of the walls of the kiln (Figure 2-4). All of the bricks in the walls were coated with glaze on the interior. Excavations followed the western wall of the kiln until they located the double chimney at the northern end, which is an unusual feature for a groundhog kiln. They also located the small entryway door that James Wilson Jr. describes climbing into and out of to access the interior of the kiln (interview with Georgeanna 
Greer, 1979, from the Institute of Texas Cultures). Lastly, they uncovered a small pile of plain lids near the entryway. In total, this work uncovered the chimney, the small doorway at the northeast corner, part of the inside of the western wall, and most of the interior of the eastern wall. These excavations were stopped when the THC decided to declare the site a State Archaeological Landmark.

Excavations at the groundhog kiln recovered numerous glazed bricks (Figure 2-5). These bricks were used in the kiln architecture and were covered with glaze on the inside of the kiln as a result of the firing process. This is a common result of the use of salt-glaze on pottery from this time period. When the salt is introduced to the hot kiln through openings in the top of the structure, a chemical reaction takes place and separates the elements in the salt, producing hydrochloric acid vapor that corrodes the bricks and eventually renders the kiln unusable (Greer 1981; Montgomery 2004). Interestingly, sites that employed salt-glazing often demonstrate a series of kilns used in this process, one being replaced by another as the process corroded the interior of the kilns, just as may have been the case at the Wilson-Durham-Chandler site (Britt 2005).

\section{Materials Collected from Kiln Excavations}

The excavations at the groundhog and beehive kilns provided much cultural material demonstrating pottery production. These materials include pottery sherds, lids, kiln furniture, six pieces of a one quart jar that was reconstructed, one other whole jar, some glass and other miscellaneous non-ceramic artifacts, and one clay marble. These materials are now in the possession of the Wilson Pottery Foundation and will be available for public exhibit and further study at the Wilson Pottery Museum in Seguin, Guadalupe County.

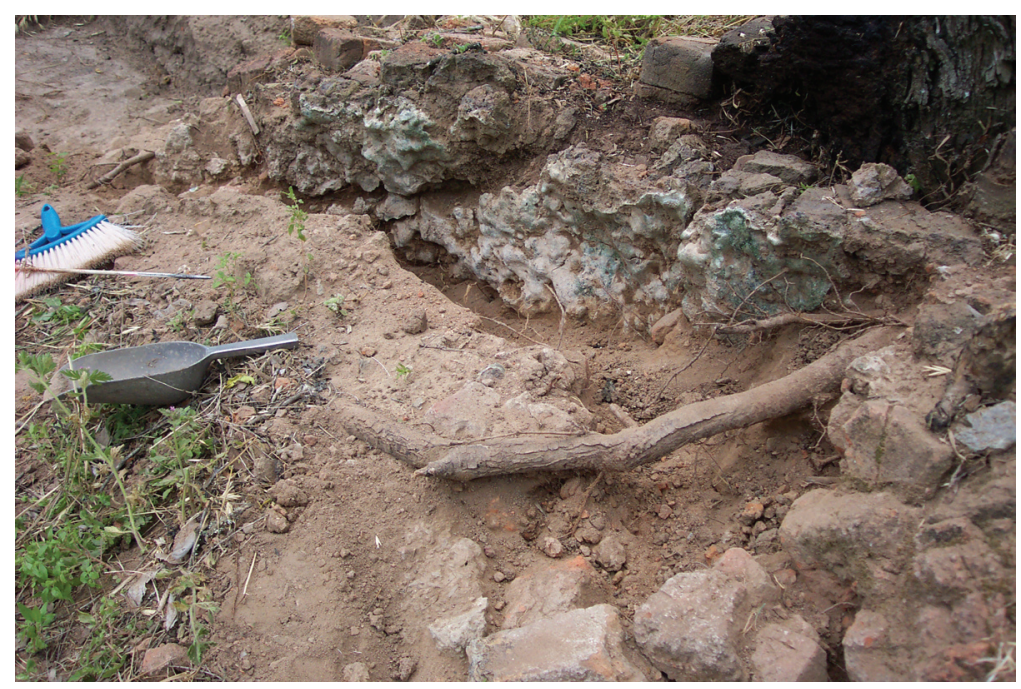

Figure 2-4. Excavation of the western wall of the groundhog kiln. 


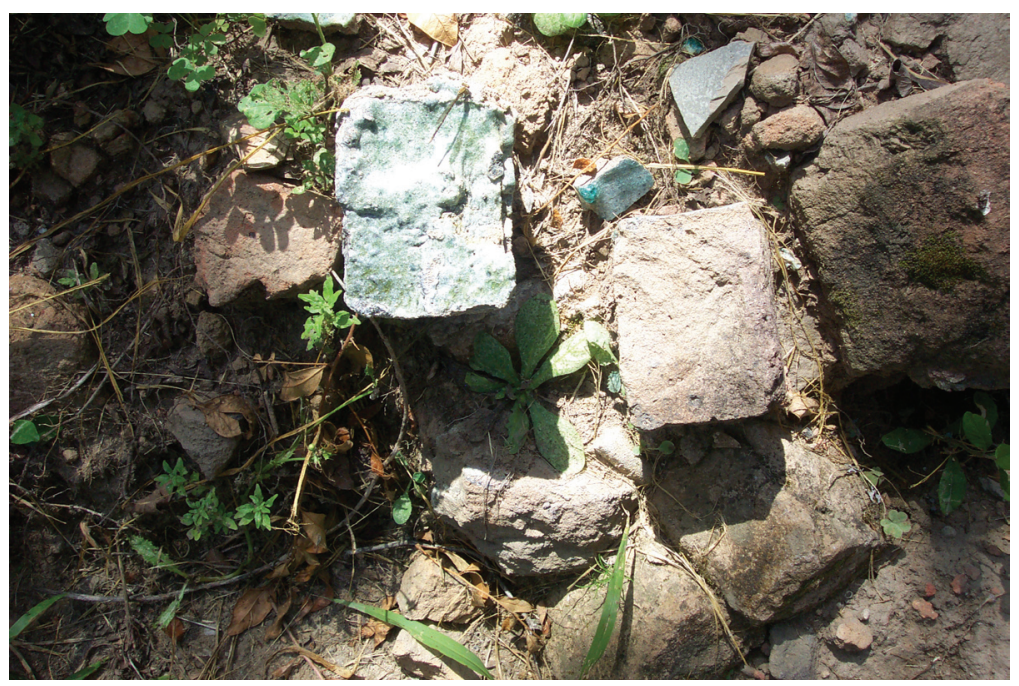

Figure 2-5. Hand-made bricks from the groundhog kiln, demonstrating glazed inside edges where they functioned as part of the architecture on the interior wall. 


\section{Chapter 3}

\section{Kiln Conservation}

Molly Morgan and Jon C. Lohse

In the winter of 2007, the Wilson Pottery Foundation, presided over by LaVerne Britt, contacted the Center for Archaeological Studies (CAS) at Texas State University for conservation work at the Wilson-Durham-Chandler site (41GU4). The foundation had received a grant to cover half of the costs for documentation and conservation from the Texas Historical Commission (THC). A contract was entered into spanning from December 2007 through June 2009. The work required under this contract includes a) the archaeological mapping and recording of the exposed kiln features, b) the backfilling of kilns for conservation, c) the collection of exposed pottery sherds, and d) the production of a research report. This chapter summarizes the completion of these tasks and records important information gained through CAS work at the Wilson-DurhamChandler site.

\section{Site Restoration}

On December 8, 2007, members of the Wilson Pottery Foundation and archaeologists from CAS and the THC did collection and clean up work at the site (Figure 3-1). This included collecting all of the pottery that had been left on sorting tables by the previous work, undertaken by Richard Kinz. Those efforts had left 17 tables along the north and south fence lines of the site, with ceramic sherds spread out across their surfaces. Preliminary sorting had been conducted, following form categories such as body sherds, rim sherds, and lids. The tables also indicated sherds that had been removed from groundhog kiln and beehive kiln excavations. Sherds were collected in 4 ml plastic zip-lock artifact bags with labels indicating site identification information and the number of the table from which those sherds had been collected. Bags of sherds were boxed by table. This collection methodology was followed in order to make best use of, at a later date, the

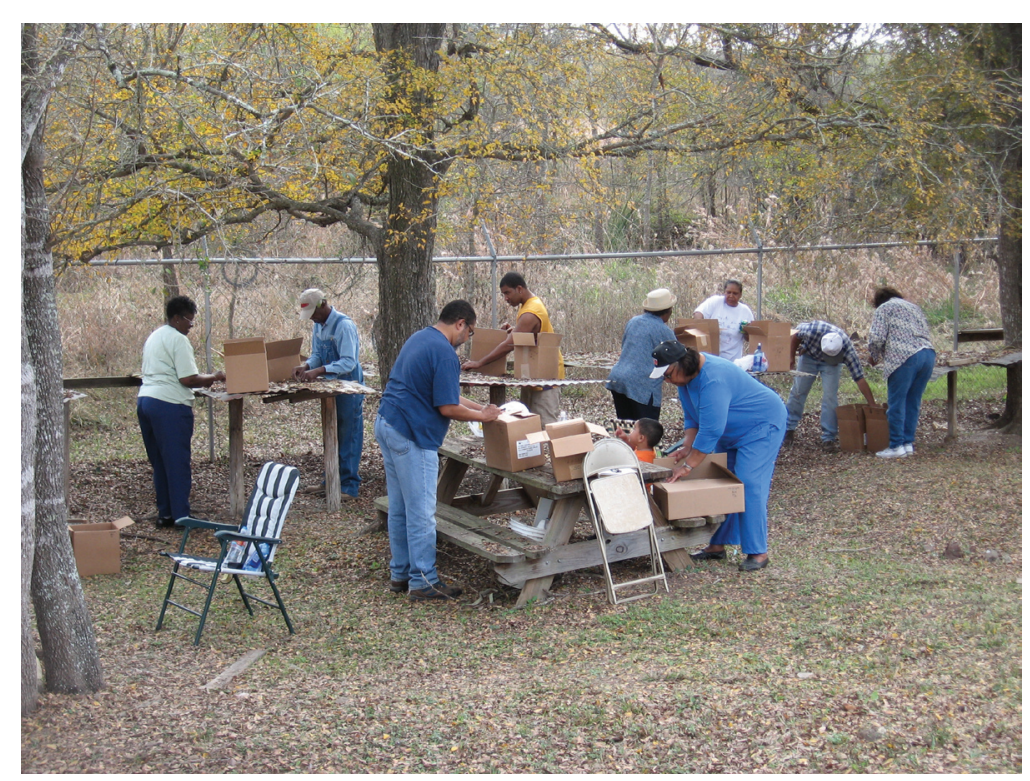

Figure 3-1. The collection of pottery sherds from sorting tables at the Wilson-Durham-Chandler site on December 8th, 2007. 
effort that had gone into sorting sherds by Kinz and his team.

Site clean up work included picking up other artifacts on the surface of the site and removing debris from past site work. Artifacts collected included bricks, glass, metal, and ceramic sherds littering the ground surface. Sherds located in waster piles on the southern side of the site were left in place, as requested by the Wilson Pottery Foundation. Debris from past work at the site included the sorting tables, buckets, and hand tools. These items were removed from the site altogether or left piled to the sides of the site, where they were later picked up for disposal. This work was done in preparation for future visits to the site as an archaeological park, to be conducted through the Wilson Pottery Foundation. Two picnic tables were left in shady spots under large trees to provide resting spots and enhance the aesthetic appeal of the area.

\section{Recording and Mapping the Pottery Kilns}

From March 4 through March 17 of 2008, CAS work continued at the WilsonDurham-Chandler site to document and record locational data from the beehive and groundhog kilns. The objective of this work was to collect as much information as possible before reburying the pottery kilns for preservation purposes. The kilns were first cleaned with the use of small whisk brushes. Then they were each photographed and drawn in plan and profile.
The beehive kiln was the most extensively excavated kiln found at the site (Figure 3-2). Inspection of the kiln revealed all walls completely exposed (Figure 3-3). Preliminary conservation measures had been taken to keep the walls from collapsing, including reconstructing support walls on the north, east, and west sides of the kiln to keep exterior walls from falling outward, and propping up existing interior architecture with large cement blocks.

Drawings of the beehive kiln highlight the architecture of this feature. Entrances to fire boxes are found on both the west and east sides (Figure 3-4). Chambers in which the pottery vessels were fired are seen on both sides of these entrances. The interior walls of these chambers had thick coatings of glaze indicating that they were used for firing salt-glazed vessels. The southernmost two chambers still exhibited remains of the vaulted roof structure (Figures 35). The bricks of these vaults are also covered with glaze, as well as encrusted pottery fragments that became adhered to their surfaces during the firing process.

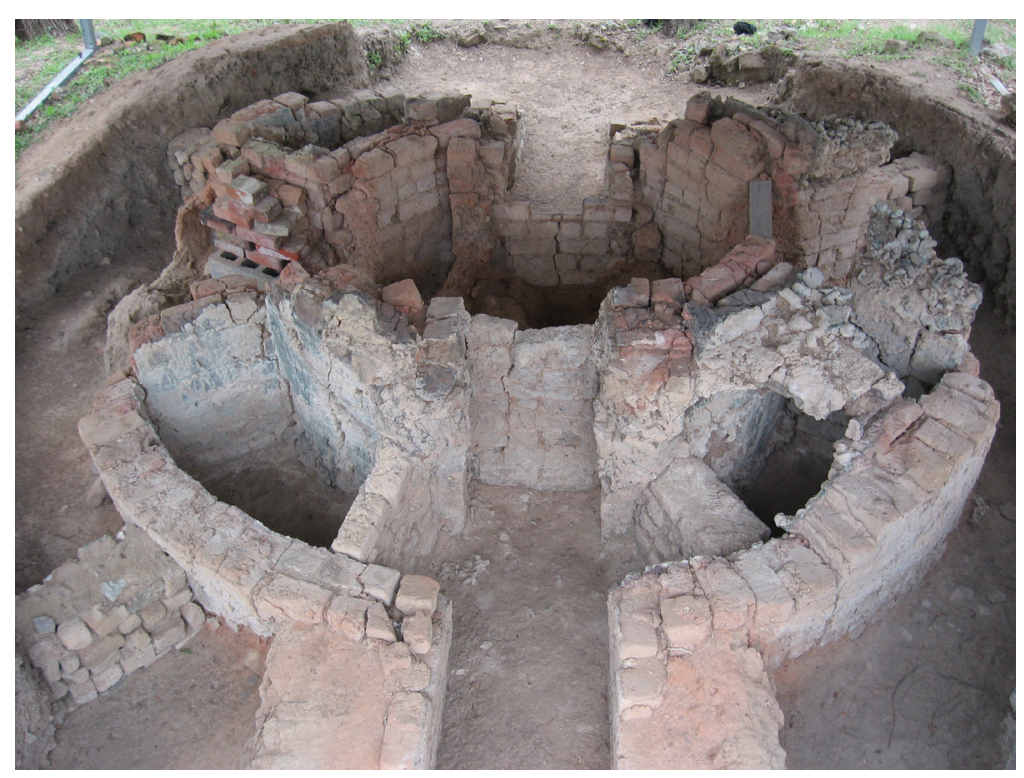

Figure 3-2. Photo of the beehive kiln, taken from the west side. 


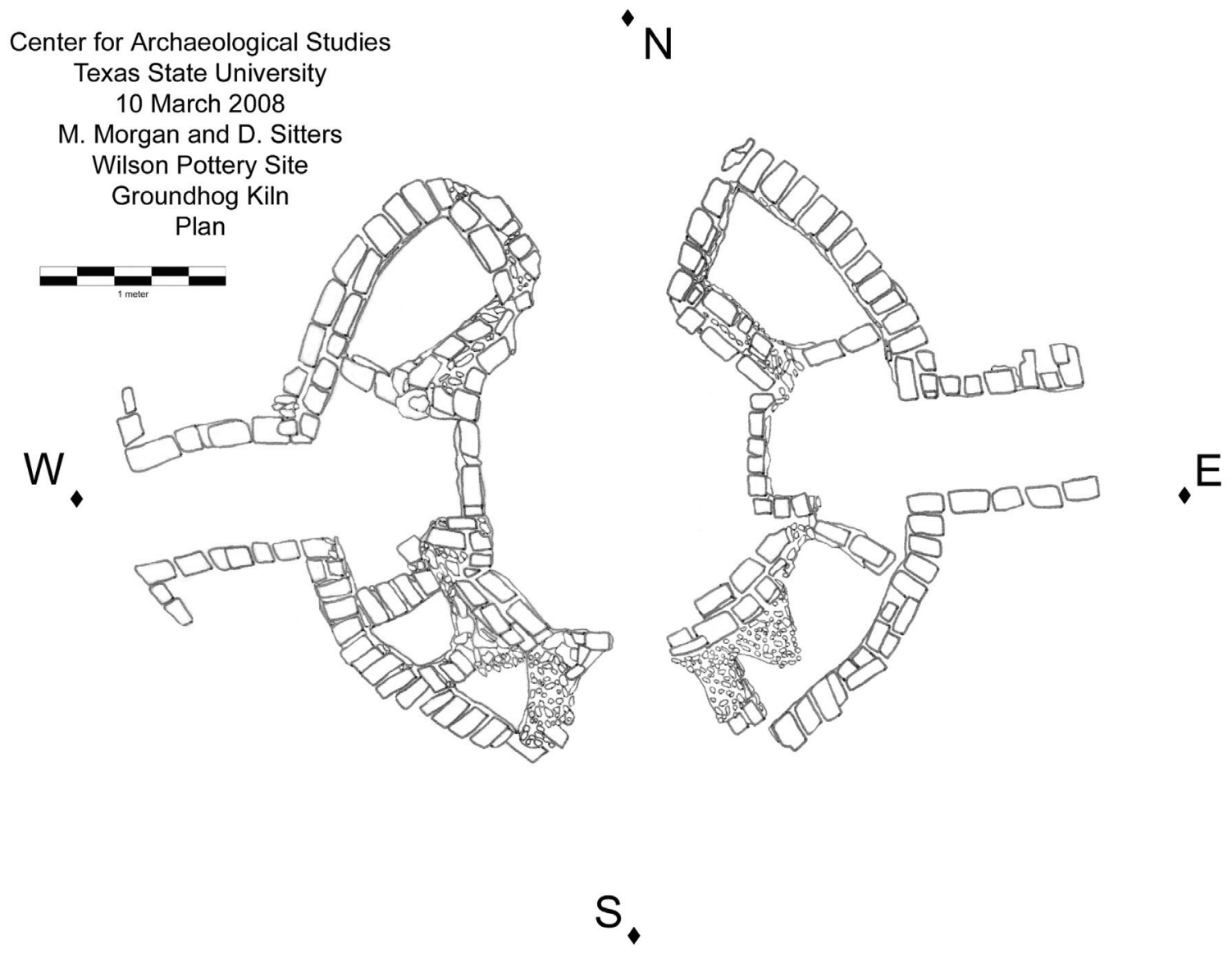

Figure 3-3. Plan drawing of the beehive kiln.

The interior circular chamber of the beehive kiln appears not to have contained pottery during the firing process, since its interior walls are not covered in glaze. The purpose of this interior chamber is still unknown. Chapter Five describes how traditional beehive kilns functioned, with lower chambers for containing the fire, and upper chambers for the pottery. It is unclear that this beehive kiln functioned in the same way. In his description of excavations at this kiln, Richard Kinz describes reaching a floor level indicating the bottom of the kiln, which would suggest that there was no lower level in the Wilson-DurhamChandler example. This floor, however, was not apparent during CAS cleaning and inspection and no test excavations were conducted past this level to view underlying stratigraphy, so we suggest

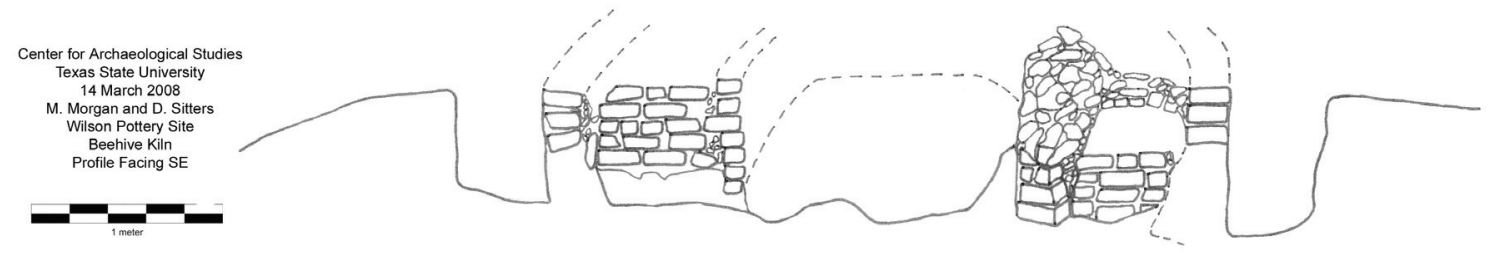

Figure 3-4. Profile drawing of the beehive kiln, facing southeast. 


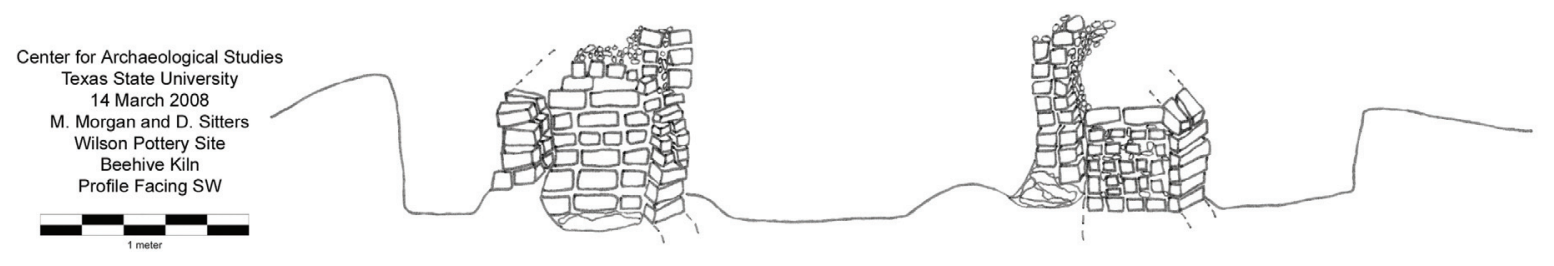

Figure 3-5. Profile drawing of the beehive kiln, facing southwest.

that it is still uncertain as to whether this kiln has two levels of chambers.

The exposed portion of the groundhog kiln was cleaned and documented through the same process as that use on the beehive kiln. This feature was not completely excavated in the past, but was exposed only at its northern end where the double chimney is located, and along the eastern wall (Figure 3-6). Past work had attempted to conserve the arches of the chimney by propping cement blocks beneath. The western chimney was found intact, but the arch on the east side was comprised of bricks that were clearly out of their original position.

The documentation of the groundhog kiln recorded parallel side walls bordering the interior chamber that would have held the pottery

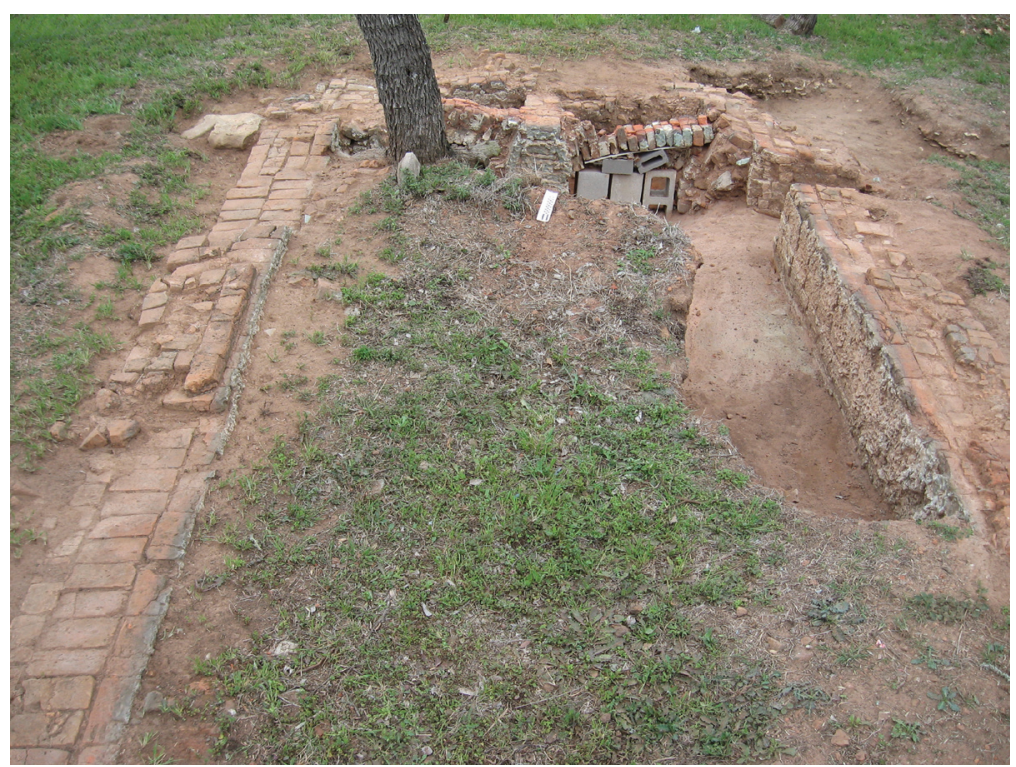

Figure 3-6. Photo of the groundhog kiln, taken from the south. during firing (Figure 3-7 and 3-8). These walls linked the chimneys at the northern end with the firebox and entrance to the kiln which would have been located at the southern end, but where little intact architecture could be detected. The interior bricks of these walls were heavily coated with glaze.

As described in Chapter Five, the double chimney is a unique feature on the WilsonDurham-Chandler groundhog kiln (Figure 3-9). The access door near the chimneys is another unique feature of this kiln (see Figure 3-7). Since it was such a large kiln, it appears that two entryways were required to access the interior chamber to stack the pottery for firing. It is also possible that this kiln was used not just to fire pottery, but also for firing the bricks that were used at the site to make the kilns, and probably for architectural features on other structures. Brick does not need to be fired at the same high temperature as pottery, so it is possible that this back entryway, farther away from the firebox at the southern end, may have been used to stack the bricks for firing. 


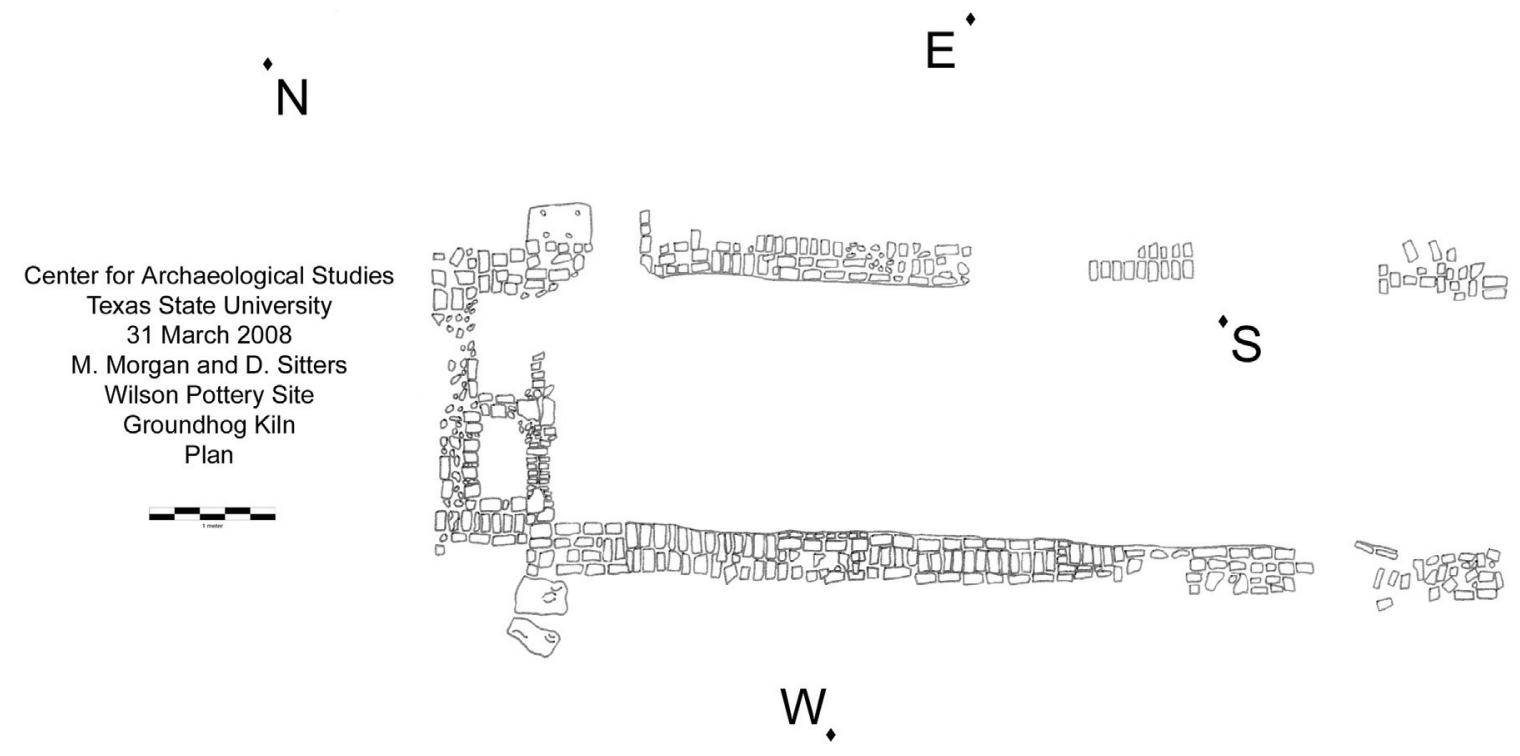

Figure 3-7. Plan drawing of the groundhog kiln.

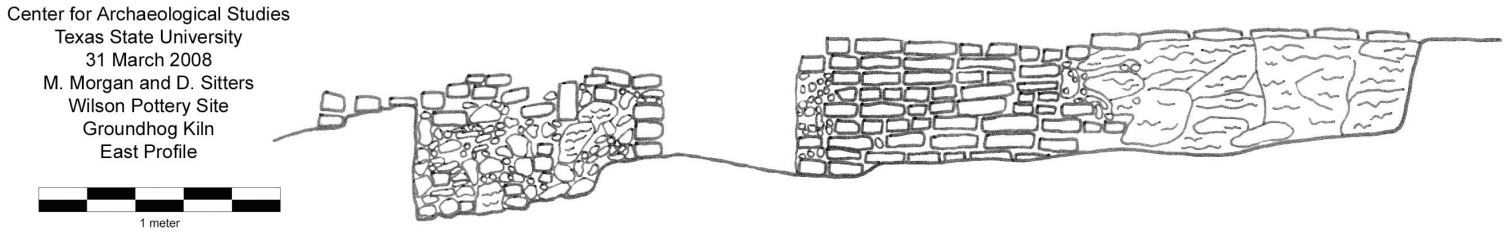

Figure 3-8. Profile drawing of the eastern wall of the groundhog kiln, from the interior.

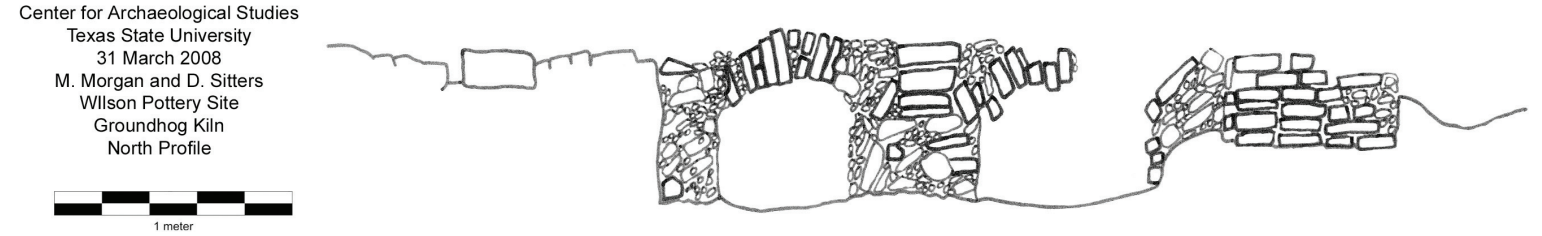

Figure 3-9. Profile drawing of the double chimney at the northern end of the groundhog kiln.

\section{Backfilling and Conservation of Pottery Kilns}

On August 4, 2008, conservation work began at the site. On this date, the THC declared the Wilson-Durham Chandler site a Texas State Archeological Landmark. State Archeologist Pat Mercado-Allinger presented the site marker to the Wilson Pottery Foundation, which was immediately planted in the ground near the entrance to the site. Wilson Pottery Foundation members ceremonially threw the first shovels of dirt onto the beehive kiln to begin the conservation work (Figure 3-10). The event was covered by 
the local press in the Seguin Gazette on August 6th and the San Marcos Daily Record on August 7 th.

The backfilling of the kilns continued throughout the month of August. Members of the CAS team packed soft, clean sand against the walls of the beehive and groundhog kilns. Soft, clean loam was then piled on top of the upper levels of both kilns. These soft sediments will hold the kiln architecture in place and preserve these kilns from further destruction.

Today, from the surface of the site, both kilns are completely covered and appear as slight hills on the topography of the site. Future visitors to the archaeological park may experience and appreciate the layout of the site by reading markers for the kiln and waster pile locations. Through publications such as this one at the Wilson Pottery Foundation Museum, they can gain information on what these kilns and other features looked like, and how they functioned at this important pottery manufacturing location in Texas history.

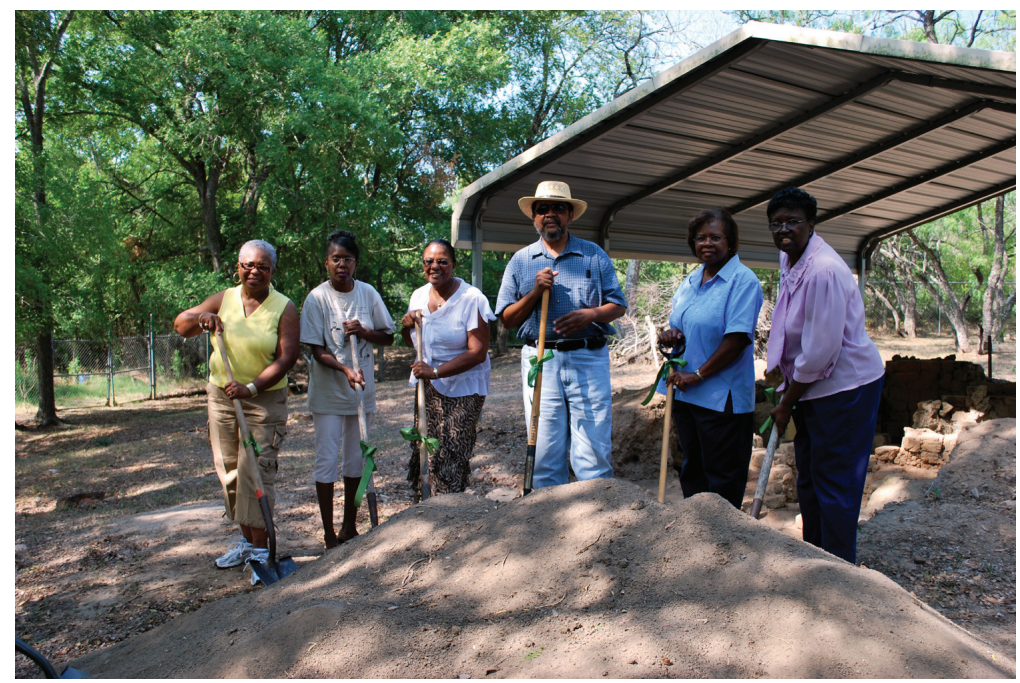

Figure 3-10. On August 4, 2008, Wilson Pottery Foundation members ceremonially threw the first shovels of dirt onto the beehive kiln to begin the conservation work. 


\section{Chapter 4}

\section{Ground Penetrating Radar Survey}

\section{Tiffany Osburn}

On September 19, 2008, the Texas Historical Commission (THC) conducted a groundpenetrating radar (GPR) survey at the WilsonDurham-Chandler Pottery site. The GPR survey was conducted in two grids to locate features related to pottery production, including previously unidentified kilns (Figure 4-1). The purpose of this chapter is to summarize the results of the survey work.

\section{Ground-penetrating Radar Survey}

Ground-penetrating radar data are acquired by transmitting pulses of radar energy into the ground from a surface antenna. These pulses are reflected off buried objects, features, or bedding

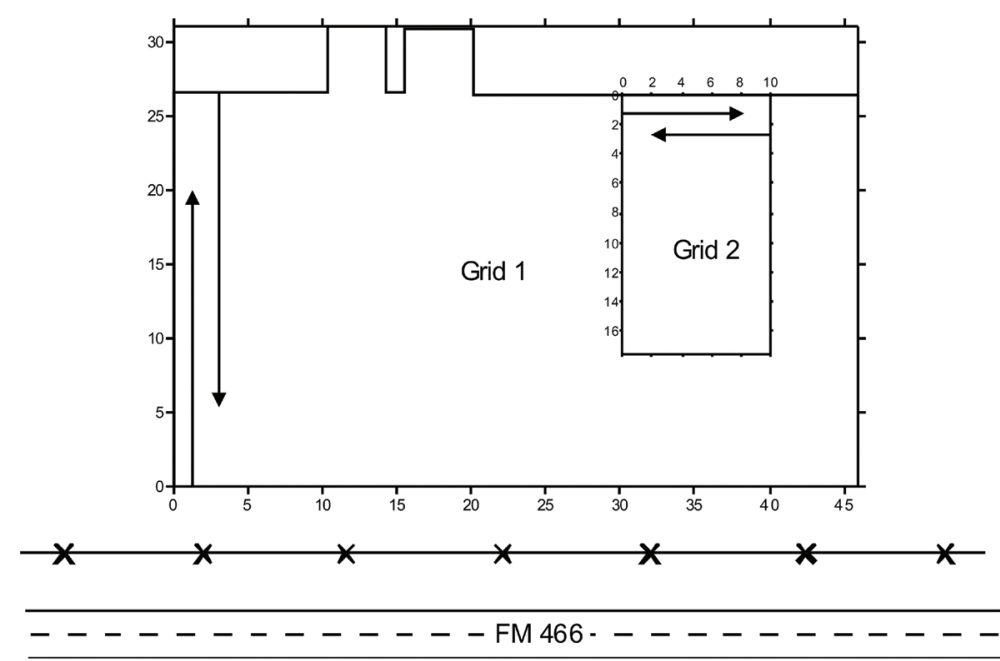

Figure 4-1. Location and orientation of GPR survey grids within the fenced area of the Wilson-Chandler-Durham site. planes and then detected back at the ground surface with a receiving antenna. The greater the contrast in electrical, magnetic, and physical properties between two materials at a buried interface, the stronger the reflected signal will be, and therefore the greater the amplitude of reflected waves. When collecting radar reflection data, the surveyor moves surface radar antennas along the ground following transects within surveyed grids (Figures 4-1 and 4-2). The resulting data are a series of reflections from each transect that may be plotted to create a two-dimensional profile. Each profile is a graphic representation of a vertical face along a particular transect (Figure 4-3).

The success of GPR surveys in archaeology is largelydependanton soilandsedimentmineralogy, ground moisture, depth of burial, and surface topography and vegetation. Electrically conductive or highly magnetic materials in the ground will quickly dissipate radar energy and prevent its transmission to depth. The best conditions for energy propagation are usually therefore dry sediments and soils. Fortunately, the Seguin area was relatively dry prior to this survey. The moderate moisture in the soil, consisting of sand over a finer subsoil on 


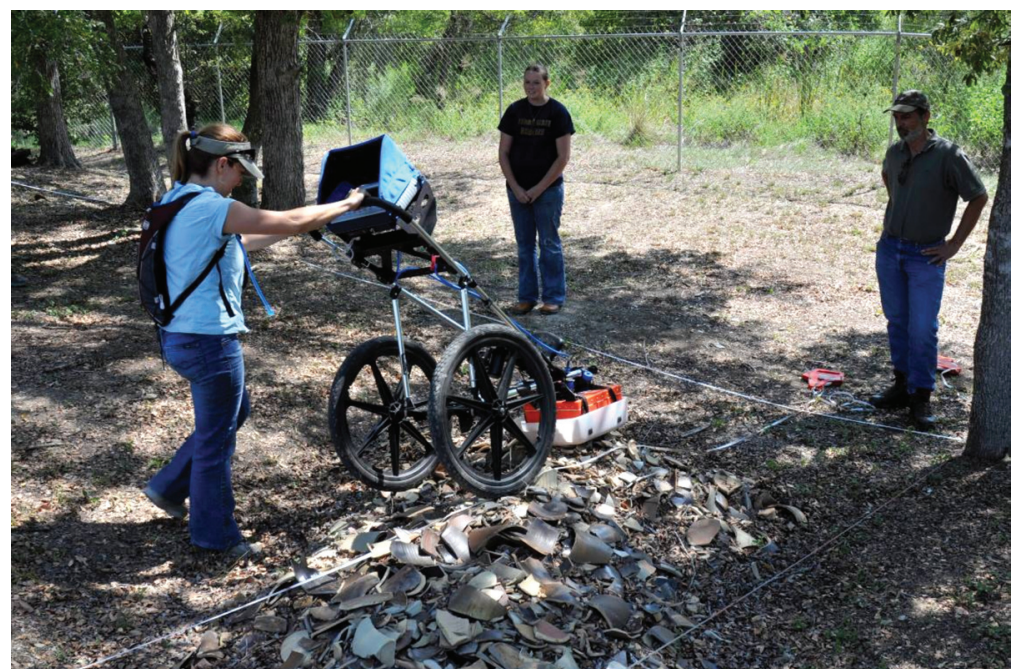

Figure 4-2. Tiffany Osburn conducting GPR survey at the WilsonChandler-Durham site. Many obstacles, including this pile of pottery, were encountered across the grid.

site allowed relatively good transmission of radar wave energy.

When reflections from objects are viewed in two dimensions they often appear as hyperbolic reflections (see Figure 4-3). These reflections are produced from buried "point sources" such as caskets or large rocks as opposed to planar surfaces. The wide angle or "footprint" of the radar beam causes the antenna to "see" the object as it moves toward it and continue to "see" it as it moves away from the buried object, resulting in a hyperbolic reflection along the transect.

The GPR system used at site 41GU4 was a Geophysical Survey Systems Inc., (GSSI) Subsurface Interface Radar (SIR) 3000 model. The GPR antenna used for the survey was a dual $400 \mathrm{MHz}$ antenna that produces a radar pulse of about $25 \mathrm{~cm}$ in wavelength. Two grids were surveyed for this project to prospect for unrecorded kilns. The survey was conducted inside the fenced area of the site and was extended as large as possible while still avoiding major clusters of trees and other obstacles. Grid 1 was laid out as a $31 \times 45 \mathrm{~m}$ area and surveyed in $50 \mathrm{~cm}$ transects collected along a north-south axis. The $(0,0)$ origin of Grid 1 is located in the northeast corner of the fenced site area (see Figure 4-1) and the corners of the grid were marked. Grid 2 was placed over a 10 x $17 \mathrm{~m}$ portion of Grid 1 and data was collected in $50 \mathrm{~cm}$ transects placed perpendicular to those of Grid 1. This was done to collect additional data over an area of interest. The results of these surveys

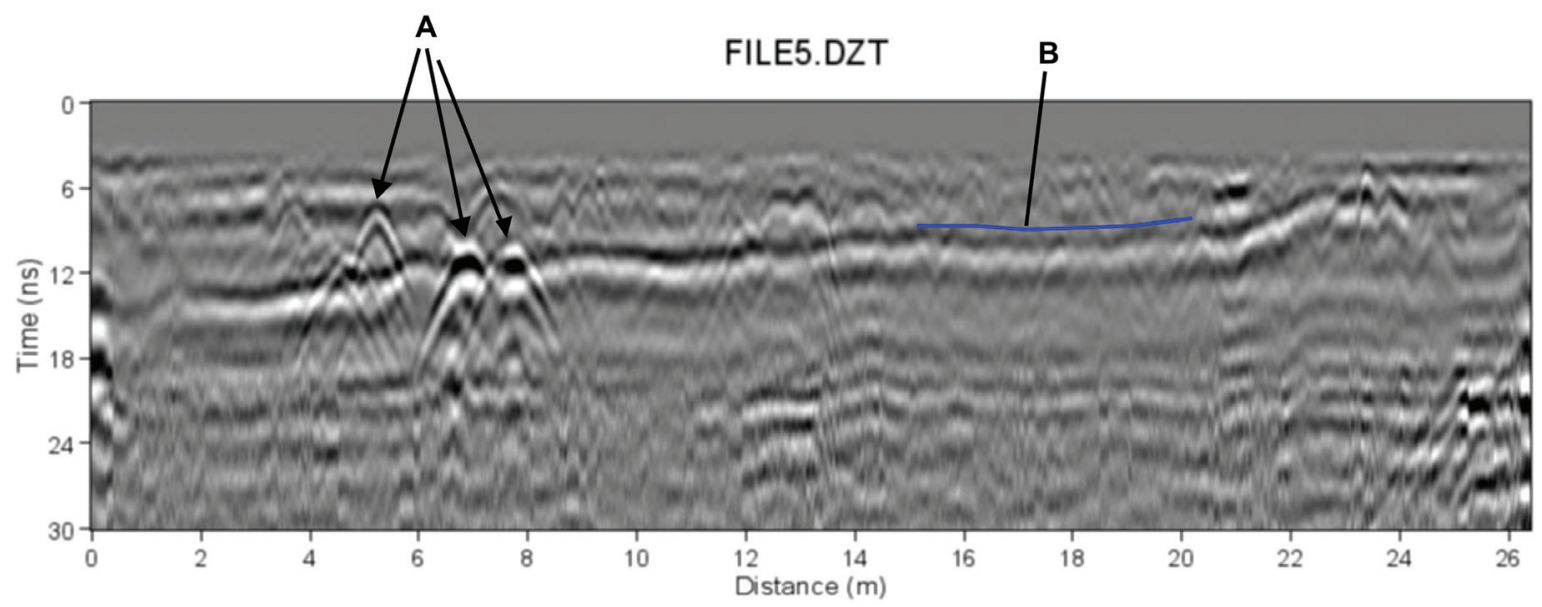

Figure 4-3. Example of a GPR profile from Grid 1 showing a series of hyperbolic reflections (A) and a bedding plane or reflection surface (B) (meters increase to the south). 
are shown in Figures 4-5 and 4-6. Each 3 ns (nanosecond) slice roughly approximates a $15 \mathrm{~cm}$ level in the ground.

One stratigraphic layer is visible in the profiles and in the radar slices as a continuous reflection surface that appears to slope to the north. Where this surface is not continuous or broken, some disturbance such as a pit, kiln, intrusive tree root or other feature is typically the cause. Near the center of the grid, in the area of the previously excavated kilns, this natural layer appears to undulate as a result of the antenna traveling over mounded areas, thus increasing the distance between the antenna and the stratigraphic layer (Figure 4-4).

The results of this survey show many anomalies that are caused by trees, tree roots, previous excavations, piles of pottery, and old backdirt piles. In Grid 1 tree roots are the predominate cause of high amplitude reflections between 0 and $15 \mathrm{~m}$ in the $\mathrm{X}$-direction. The roots are mainly visible in slices 1-4 and form linear anomalies that could easily be misinterpreted as cultural features (Figure 4-5).

This survey identified the location of several features of interest (Figure 4-6). Feature B is a noncultural linear anomaly that is the result of amplitude slice 4 cross-cutting the sloping plane of a stratigraphic layer. Feature $\mathrm{C}$ is a burn pile at the surface that caused a distorted reflection throughout the profile. Features A and D warrant some investigation to determine their association with the historic pottery manufacture at the site. While the reflection data do not clearly indicate buried kilns, analysis of the individual profiles as well as the time slices indicate that these features may be cultural and are not the result of tree roots or surface disturbances.

In summary, remote sensing was productive in identifying two features that warrant further investigation. Features A and D (see Figure 4-6) appear to be cultural and may represent previously unidentified kilns associated with the WilsonDurham-Chandler Pottery site. Unfortunately, other cultural features associated with historic pottery making were likely obscured as a result of surface disturbance and tree growth.

\section{FILE38.DZT}

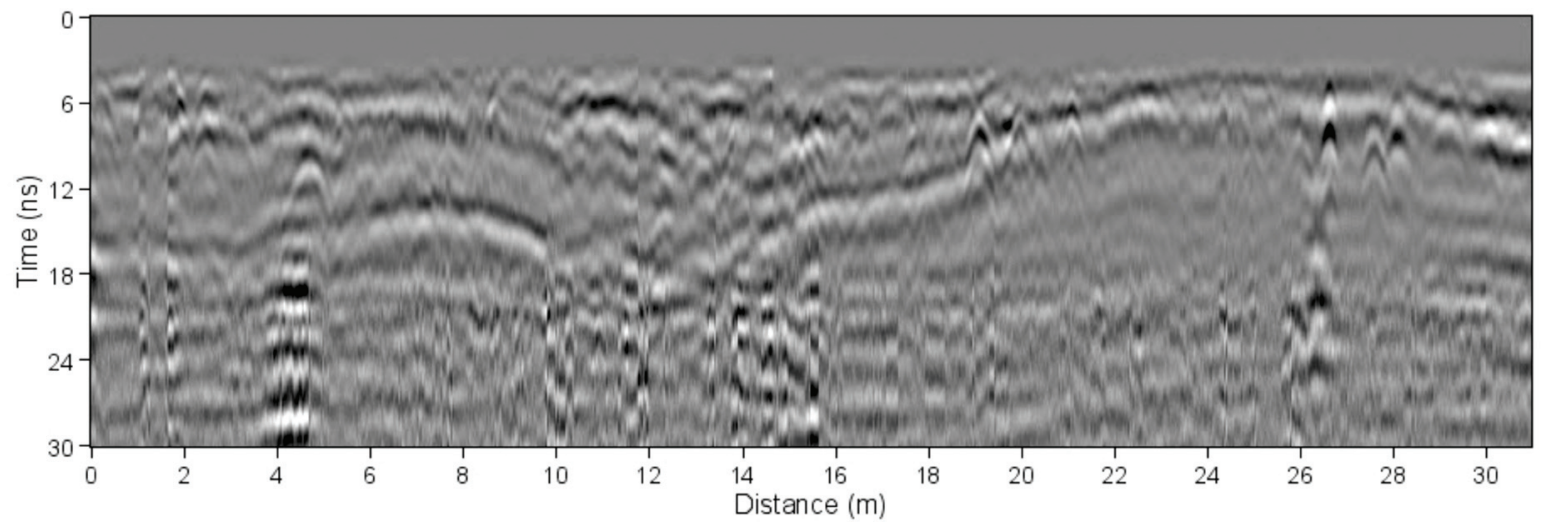

Figure 4-4. Natural stratigraphic layer appears to undulate when the antenna travels up and down over surface features. 

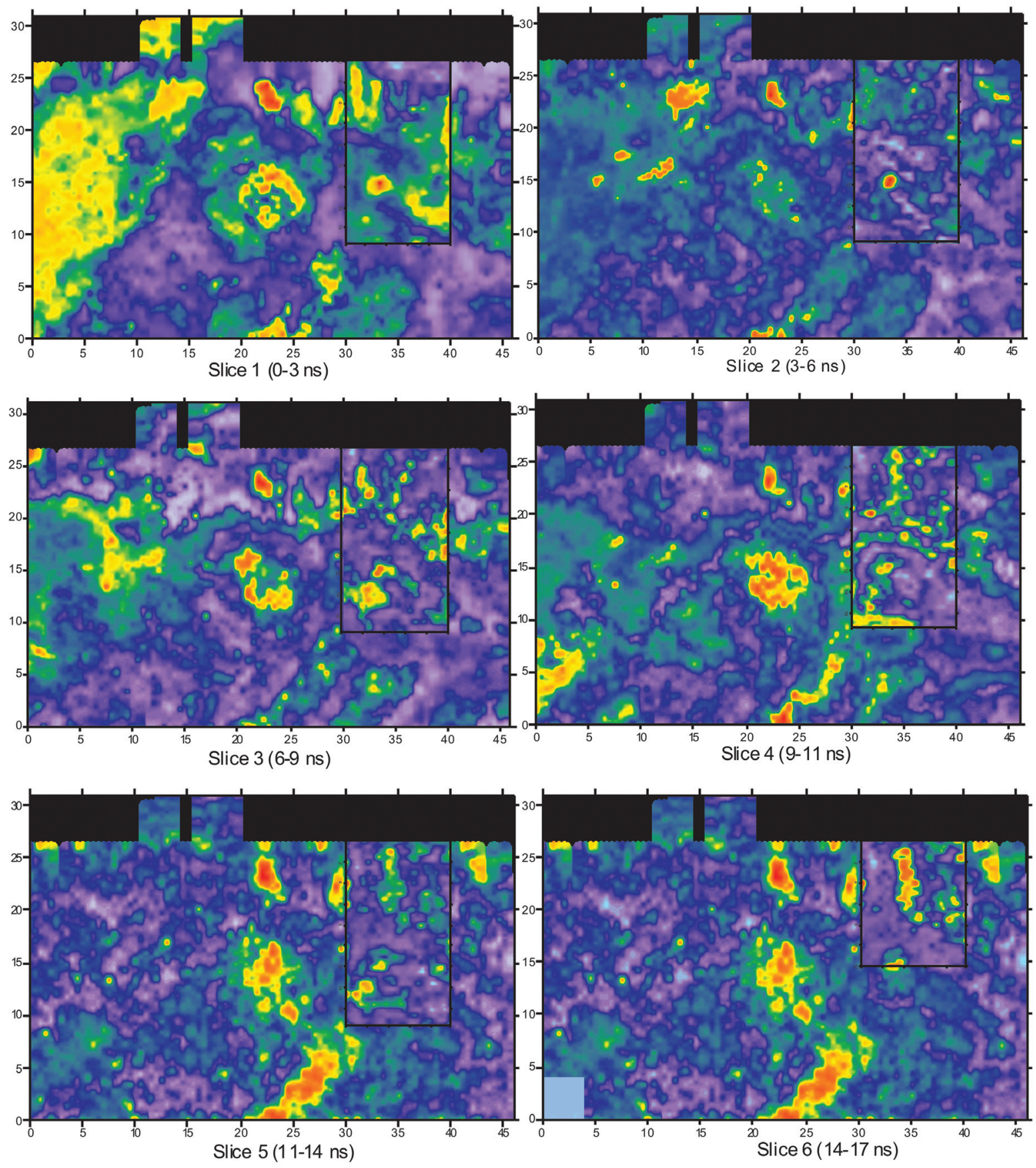

Figure 4-5. GPR amplitude slice maps of data collected over Grids 1 and 2 (grid in meters). Amplitude slices 1-6 (0-17 ns). High amplitude reflections are seen as "warmer" colors, greens, yellows, and reds. 

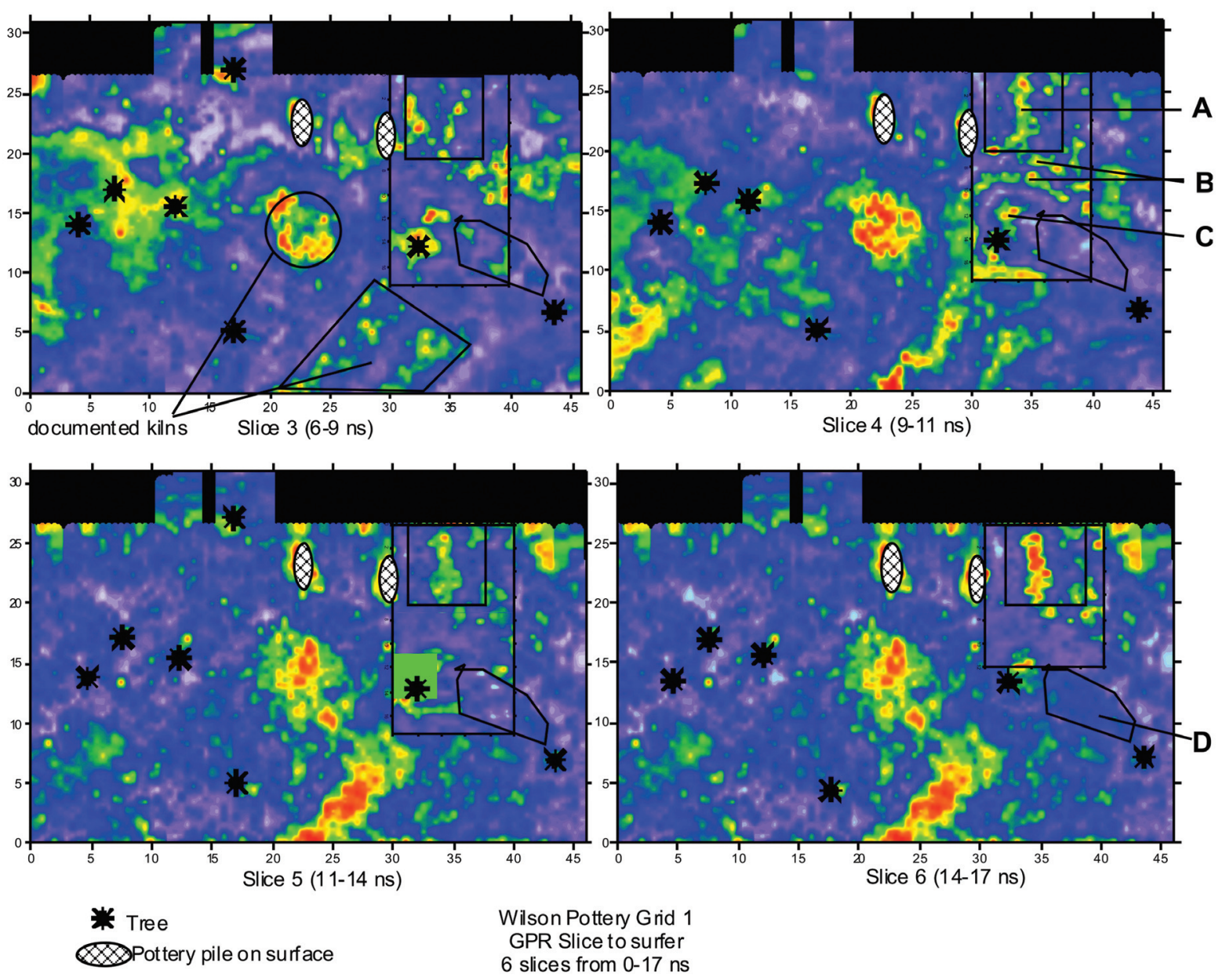

Figure 4-6. GPR amplitude slice map 5 (20-25 ns; grid in meters) showing potential features. 


\section{Chapter 5}

\section{Wilson Pottery}

Molly Morgan

The production of stoneware utilitarian pottery was an important economic and artistic endeavor in the 19th century in most regions of the United States. Before modern refrigeration, the storage and preservation provided by such vessels was crucial to most households. Businesses that could put such items on the market were generally successful. The Wilson Potteries are an example of such a business. This chapter provides background information on utilitarian stoneware production and the techniques that would have been used at the Wilson Pottery sites. It also summarizes information gained from the pottery collected from the Wilson-Durham-Chandler site (41GU4).

Pottery production in Texas was heavily influenced by the Edgefield District tradition from South Carolina. In 1850, Edgefield was the home of five pottery manufacturing businesses. The many people employed in these manufactories saw entrepreneurial opportunities in Westward Expansion, which opened up areas where pottery was in high demand. The first potteries in Texas were worked by people that had been trained in Edgefield or were influenced by those who had moved west taking stoneware pottery production knowledge with them. In the $1840 \mathrm{~s}$ and $1850 \mathrm{~s}$, small pottery production workshops were located in central and eastern Texas (Brown 2002).

\section{Pottery Production}

The pottery produced at the Wilson sites, as well as many potteries in Central Texas, reflected the Edgefield style of utilitarian stoneware. Pottery was produced at this time with the use of a potter's wheel. Clay is widely available in Texas, and can be collected from many streambeds. Wilson Pottery was made from the fine clay recovered from Salt Creek, which has a geological origin from the Carrizo Sands of the Wilcox Formation (Blake, Johnson, and Kinz 1999; Brackner 1981). This geological deposit extends from western Alabama through Central Texas. The high quality of this clay was an important factor contributing to the growth of pottery manufacturing businesses in Texas. It allowed for the production of stoneware pottery, which is between earthenware and porcelain in hardness and vitrification, which depends on the silica content in the clay and the firing temperature (for stoneware, a temperature of 1200-1300 degrees $\mathrm{C}$ is necessary). The clay found along Salt Creek in Guadalupe County worked well for stoneware production, with only the addition of fine sand necessary for the desired vitrification.

To produce pottery containers, the clay would be mixed with additive ingredients (in the Wilson case this included silica), left to dry and age, and then moistened again and ground on a mule-drawn pug mill. The clay was shaped into jars, jugs, crocks, churns, and cemetery flower jars on a kick wheel. Each piece was removed 
from the stone base of the pottery wheel by pulling a wire across the bottom of the pot. After a brief period of drying, the vessels were decorated with slip (a combination of clay and water) or one or both of two types of glaze (Brackner 1981; Greer 1981). On Wilson pottery, brown slip was usually applied only to the interior, but occasionally appears on the entire vessel surface, especially in the 1890 s when this was the popular style (Greer, n.d.b.).

The first type of glaze, alkaline glaze, is made through a combination of wood ash or lime, clay, sand, and water, ingredients all readily and cheaply available in the southern United States. This glazing tradition came directly from the Edgefield District of South Carolina, where it may have been copied from an English pottery making style that mimicked an ancient Chinese glaze formula (Greer 1981). After the ingredients for the glaze were mixed and sometimes ground on a glaze mill, the alkaline glaze was applied to the exterior of the vessel by pouring it over the pot or by dipping the pot into a vat of prepared glaze. Alkaline glazes can take many colors, depending on the nature of the ingredients, but generally fall within the creamy tan to brown to very dark brown color range and exhibit some type of texture, such as visible inclusions, mottling, or streaking. The alkaline glazed pottery from the Wilson sites generally takes on a greenish, glassy surface appearance, a common color for this type of glaze (Brackner 1981; Greer 1981).

The second type of glaze used at the Wilson Pottery sites is salt glazing. First used in Germany in the fifteenth century, salt glazing utilizes a chemical reaction that takes place when salt is thrown into a hot kiln to produce a hard and transparent glaze (Greer 1981). In the nineteenth century United States, it was primarily a northern pottery-making technique, although the Wilson Pottery sites are only a few of the examples that used salt glaze in the south (Brackner 1981). To make the salt glaze, common rock salt was thrown into the kiln in the middle of the firing process, when a high level of heat had been achieved and the surface of the pottery was close to the vitrification point (1200-1260 degrees $\mathrm{C}$ ). The salt-glazing process achieves a pleasant "orange-peel" or dimpled texture to the exterior glaze of these pots, adding to their appearance and enhancing their durability (Britt 2005; Humphreys and Schmidt 1976).

Salt glaze is traditionally associated with the beehive kiln, but it seems that Wilson potters employed both alkaline and salt glaze techniques in each of the two kiln types that they used (beehive and groundhog kilns are described below). Both salt glazed and alkaline glazed pottery are found at the John McKamie Wilson site (41GU6), where only one groundhog kiln has been identified. Interestingly, it seems that John McKamie Wilson only later introduced salt glazing at his Guadalupe Pottery, as evidenced by the stratigraphic distribution of these sherds (Brackner 1981). Georgeanna Greer (n.d.a.) suggests that the use of the salt glaze was most popular in Texas between 1880 and 1900. It seems that John McKamie Wilson used alkaline glaze exclusively, perhaps until the salt glazing technique was brought to his pottery by Marion Durham, John Chandler, or perhaps another traveling potter, Isaac Suttles, who went on to start his own pottery in Wilson County in 1872 (Brackner 1981; Greer 1985). Other new innovations appeared at the same time, including hand built handles that replaced wheel thrown lugs and rounded lips made for tying down lids with a cloth.

At the later H. Wilson and Company site, potters also used the salt glazing technique, again with only a groundhog kiln (Brackner 1981). Lastly, at the Wilson-Durham-Chandler site, 
both alkaline glaze and salt glaze were employed, probably being used in both the groundhog and beehive kilns, judging from the amount of glaze on the interior architecture on both excavated kilns. Following the close of this site and the start of the 20th Century, stoneware pottery changed stylistically in Texas, with white Bristol glaze replacing alkaline glaze, salt glaze, and the use of clay slips (Greer, n.d.b.).

\section{Pottery Kilns}

Two types of pottery kilns were employed at the Wilson-Durham-Chandler Pottery site, the groundhog kiln and the beehive kiln. Both types of kilns were constructed of hand-made bricks made with local, low quality red clays. These clays were hand-mixed, coated with sand, and shaped using a rectangular mold. Lastly, they were baked at a low temperature, perhaps with the pottery, but stacked at the cooler end of the kiln instead of near the firebox (Brackner 1981; Britt 2005).

The first type of kiln employed by the Wilson potters is the groundhog kiln. Groundhog kilns were unique to pottery manufacturing businesses of the south in the 19th century. These kilns are usually built into a hillside, with a doorway to the firebox at the base of the hill opening up to a long, low interior chamber (Figure 5-1). The interior of the kiln was built in a rectangular shape into the side of the hill so that the back end was entirely subterranean. The underground end of the kiln had a chimney that pulled the hot air from a firebox near the entryway, through the rectangular chamber where the pottery was baked, up and out into the surrounding atmosphere.

The pottery was loaded into the kiln by a small individual, often a child, by entering through the front firebox and stacking the unfired pottery with the use of small, hand-shaped pieces of clay, also called kiln furniture. Many examples of kiln furniture chunks were uncovered at the WilsonDurham-Chandler site. These pieces of furniture include bobs (Figure 5-2), or wads of soft clay shaped by hand by the individual loading the kiln, and stackers, or small rectangular sections of hardened clay placed between vessels (Brackner 1981).

The second type of pottery kiln used to produce Wilson pottery is the beehive kiln. As opposed to the horizontal space of the groundhog kilns, beehive kilns are much more vertical and have high vaulted roofs (Figure 5-3). Pottery fired in beehive kilns was stacked in several layers,

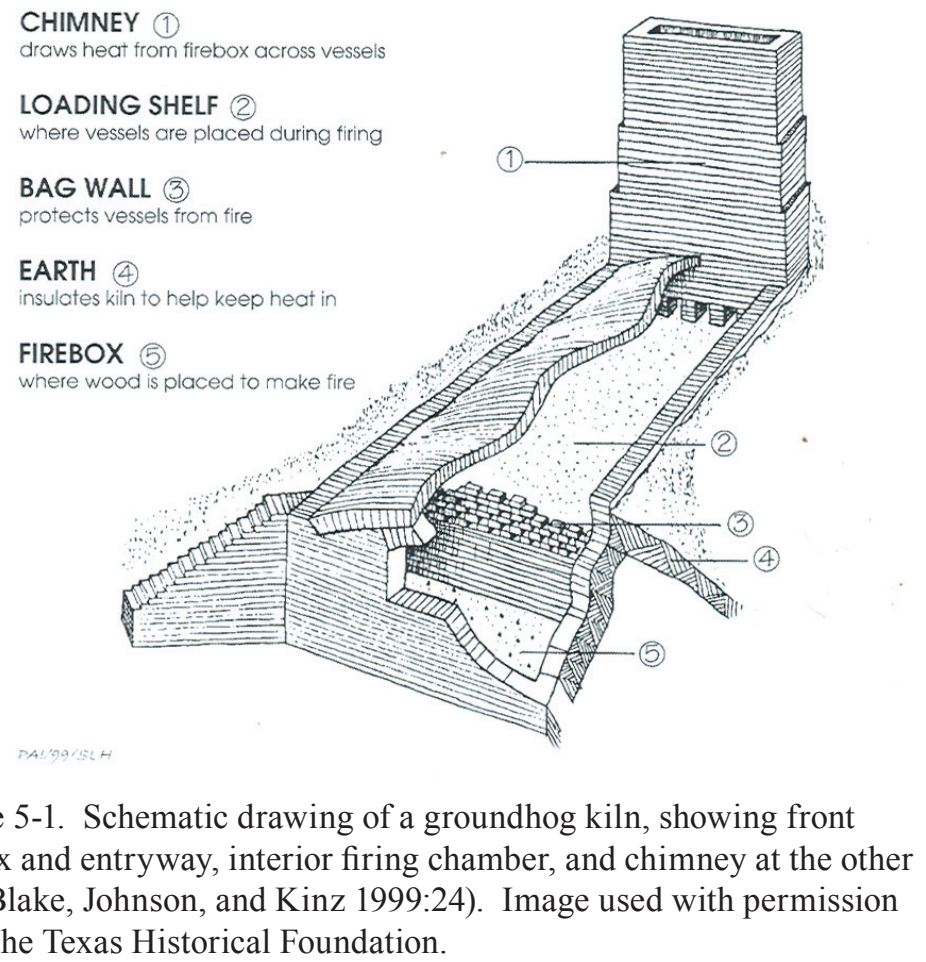

CHIMNEY

LOADING SHELF

where vessels are placed during firing

BAG WALL 3

protects vessels from fire

EARTH (4)

insulates kin to help keep heat in

Figure 5-1. Schematic drawing of a groundhog kiln, showing front firebox and entryway, interior firing chamber, and chimney at the other end (Blake, Johnson, and Kinz 1999:24). Image used with permission from the Texas Historical Foundation. 

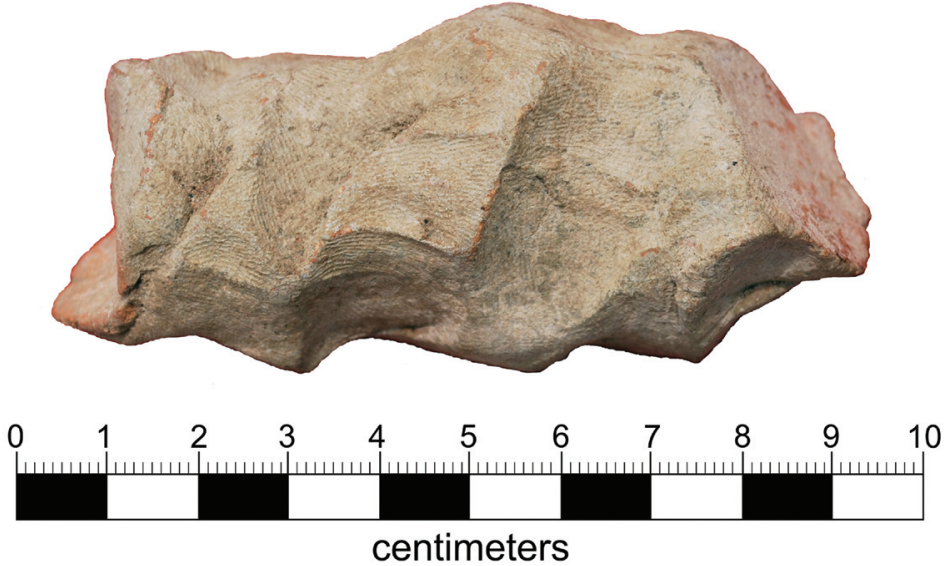

Figure 5-2. Photo of a bob (type of kiln furniture) collected from the Wilson-Durham-Chandler Pottery site. Notice the finger impressions made by the individual loading the vessels into the kiln.

requiring much kiln furniture (Brackner 1981). In fact, most of the kiln furniture collected at the Wilson-Durham-Chandler site comes from the beehive kiln that was found and excavated there (Richard Kinz, personal communication 2009). In beehive kilns, the fireboxes are located below the cavities where the ceramics were stacked. At the Wilson-Durham-Chandler site, it is unclear that the interior of the beehive kiln was excavated to the bottom levels, so this type of architecture was not possible to verify. Rather, the fireboxes and pottery chambers were found on the same level (see Chapter 3, Figure 3-3). The height of this kiln was also impossible to discern, as the kiln had been looted several time and all roof materials had collapsed into the center of the kiln (see description of beehive kiln excavation in Chapter 2).

\section{Center for \\ Archaeological Studies Collection of Ceramic Sherds}

The Center for Archaeological Studies collected 16,007 pottery sherds from the surface of the Wilson-DurhamChandler site (Table 5-1). Most of these sherds had already been collected, sorted, and stacked on tables at the edges of the site by Richard Kinz and his team. Following the initial sorting conducted by that group, CAS counted 10,653 pottery sherds from the beehive kiln and 5,354 from the groundhog kiln. Of the sherds collected, the majority (62\%) are body sherds, also with a high frequency of rim sherds (7\%) and bases (10\%). There are a large number of lids $(1,553$, or $10 \%$ of total) in the collection. Some other notable finds include jug tops, maker's stamps, kiln furniture, and handles.

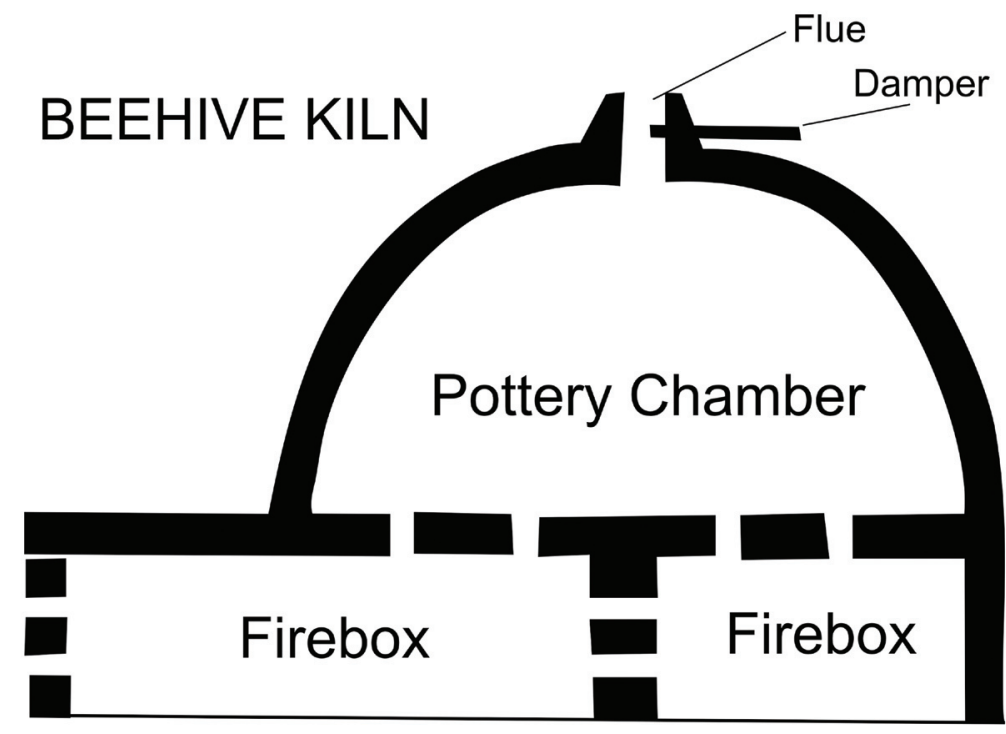

Figure 5-3. Schematic drawing of a beehive kiln. Firebox chambers and the pottery chamber can be seen. 
Table 5-1. Counts of ceramic sherds collected from the groundhog kiln and beehive kiln at the Wilson-Durham-Chandler site (41GU4) by the Center for Archaeological Studies.

\begin{tabular}{|l|c|c|c|}
\hline \multicolumn{1}{|c|}{ Sherd Type } & $\begin{array}{c}\text { Groundhog } \\
\text { Kiln }\end{array}$ & $\begin{array}{c}\text { Beehive } \\
\text { Kiln }\end{array}$ & Total \\
\hline Lids & 958 & 359 & 1,317 \\
\hline Lids with Knobs & 176 & 60 & 236 \\
\hline Jug Tops & 104 & 135 & 239 \\
\hline Sherds with Stamps & 28 & 21 & 49 \\
\hline Fumiture, Etc. & 201 & 427 & 628 \\
\hline Handles & 120 & 272 & 392 \\
\hline Rim Sherds & 404 & 757 & 1,161 \\
\hline Bases & 475 & 1,098 & 1,573 \\
\hline Body Sherds & 2,687 & 7,282 & 9,969 \\
\hline Rim and Base & 4 & 9 & 13 \\
\hline Dishes & 197 & 233 & 430 \\
\hline Total & 5,354 & 10,653 & 16,007 \\
\hline
\end{tabular}

The sample collected by the Center for Archaeological Studies did not comprise a representative sample of pottery from the site and therefore could not be used in a detailed ceramic analysis. There are two reasons for this. First, the pottery collected from 41GU4 had been excavated and sorted previously through unsystematic methods by the excavation team of Richard Kinz. Provenience information for different types of ceramics found throughout the site is unknown. It is also believed that much pottery was removed from the site during and following these excavations. Second, Kinz brought pottery from other collections to 41GU4. Under a large tree near the entrance to the site, a pile of stoneware pottery, clearly not Wilson pottery, was visible until its removal in May of 2009. Kinz also reports that he moved pottery that Georgeanna Greer collected previously from a waster pile at the site, and returned it to one of the piles. For these reasons, it is difficult to say with certainty that all of the pottery sherds found at the Wilson-Durham-Chandler site were actually produced there, and it would be impossible to accurately determine distributions across the site of various types of pottery.

All of the pottery sherds collected by the CAS were temporarily curated at the CAS laboratory facility at Texas State University, San Marcos for the duration of the study. Following the termination of this research, they will be returned to the Wilson Pottery Foundation for housing at the museum in Seguin, and for viewing by visitors and potential study by future scholars.

\section{Conclusions}

As described in this section, the Wilson potters produced alkaline-glazed and salt-glazed stoneware pottery of utilitarian forms in beehive 
and groundhog kilns. One of the most interesting aspects of pottery production at these sites is in the transitions that can be seen throughout the duration of stoneware production at the three sites. Pottery remains from the $\mathrm{H}$. Wilson and Company site demonstrate attributes such as horseshoeshaped handles, jug rim-handle attachments, and a stamp with the company's name that were not found on vessels made at the other production sites. Rather, at the John McKamie Wilson site and the Wilson-Durham-Chandler site, crescent shaped handles and tie-down lids were more common, and the application of a stamp was not used (Britt 2005; Blake, Johnson, and Kinz 1999). These new innovations demonstrate a freedom of expression in craftsmanship that likely mirrored transitions in status occurring for African Americans during this transitional time in the history of Texas. 
Chapter 6

\section{Conclusions:}

\section{A Social Role for Archaeology and the Future of the Wilson Pottery Sites}

Molly Morgan

This report summarizes archaeological work at the Wilson-Durham-Chandler Pottery site, 41GU4. This work is important for several reasons. First, the documentation and conservation of this site by the Center for Archaeological Studies (CAS), the Texas Historical Commission (THC), and the Wilson Pottery Foundation provides and protects information pertinent to the understanding of transitions in the socioeconomy of African American Texans directly following the Civil War and emancipation. Understanding the developments occurring at this time in the nation's history is crucial to building a more informed U.S. history.

The remains of the site also provide material means for contemporary citizens to transmit social memory that aids in constructing and maintaining social identity. This example underscores the role of archaeology not only in uncovering data used to reconstruct important aspects of culture history and past societies, but also in fulfilling a more social role for archaeology. This role is performed by presenting information that is used by modern groups to form identities within society today that are rooted in events of the past. When the Wilson Pottery Foundation granted permission for the establishment of the WilsonDurham-Chandler site as a State Archaeological Landmark by the THC, and worked toward the creation of a museum to educate the public on events that occurred at the Wilson Pottery sites, they began the process of providing fundamental opportunities for their members, the James and Hiram Wilson families, and for the public to engage with these materials and use the information gained through archaeology to make connections to historical events.

\section{The Social Role of Archaeology at the Wilson Pottery Site}

The Wilson-Durham-Chandler Pottery site provides an important opportunity for links to be made between modern descendants of the James and Hiram Wilson families and their ancestors. The site itself physically and symbolically links the living and the dead members of these families through material culture and the use of space. I argue that the remains of pottery vessels and the pottery workshop documented and conserved at the Wilson Pottery sites and museum serve as material symbols for the social memory that has been appropriated in recent years by the descendants of the Wilson potters and used to construct and maintain their identity as descendants of important people in Texas history.

LaVerne Lewis Britt, great-great-grand daughter of Hiram Wilson, founded the Wilson Pottery Foundation with twelve other members of the board of directors in 1999. The foundation works to acquire and preserve Wilson Pottery sites, and teach the public the history of the Wilson Potters. Members of the foundation 
receive a quarterly newsletter called "The Wilson Pottery Shop Chronicle" that continues to spread awareness of the Wilson pottery sites and developments in the foundation.

Britt has traced her family genealogy, recording descendents of all eleven children of Hiram Wilson and the seven children of James Wilson. That work is recorded in her book, $M e$ and My Folks, available through the foundation. After contacting her extended relatives, Britt and others organized a family reunion in 1987, as described in her other book, In Praise of Hiram Wilson. In 1990 another reunion took place, including the descendants of both Hiram and James Wilson. By 2002 the Wilson family reunions had become regular events, with over 600 Wilson descendants in attendance.

With such strong family support, the foundation has had several successes in promoting increased appreciation for their family heritage. The knowledge of the Wilson potters that has been provided through historical archaeology helps to foster the sense of pride that this group feels toward the accomplishments of their ancestors. This pride is a significant part of their social identity as they seek public recognition. The direct link between the material remains of Wilson pottery activity and the contemporary construction of this social identity can be seen in three ways: through the collection of Wilson pottery, in the appropriation of the physical space of the Wilson-Durham-Chandler site and subsequent use by the Wilson Pottery Foundation, and in the construction of a Wilson Pottery Museum in Seguin to exhibit objects and disseminate information to the public.

First, family members have discovered the worth of the Wilson pots through collectors' publications, but have chosen to value them not for financial reasons, but as tokens of their own history. Le Juene Embry Montgomery (a Wilson descendant) states about her family's appreciation of Wilson pottery, "We value these artistic treasures today because they represent a unique part of history whether it is Americana, Texas, or African American history" (2004:3). Since the formation of the Wilson Pottery Foundation, collectors pieces of Wilson Pottery have been acquired and saved for exhibition in the future museum. LaVerne Britt purchased the first pot for this purpose from Mrs. Esther Headrick of New Braunfels. Since then, several pieces have been donated and purchased by the foundation.

Wilson pottery vessels are modest utilitarian pots used for the simple purpose of storing and preserving foodstuffs. However, today they have a significant symbolic value as they represent the works of freedman labor and advancement in an important time in this country's history. For this reason, obtaining these pottery works is an explicit and ongoing goal of the Wilson descendants.

Second, ownership of the Wilson-DurhamChandler site, accomplished by the Wilson Pottery Foundation in 1999, provides the family with direct access to the pottery workshop and the spaces in which their ancestors labored. Family members worked to clear the land and Richard Kinz took charge of recovering remains of the pottery manufacturing business. As early as 2005, LaVerne Britt, president of the Wilson Pottery Foundation, saw a need to stop excavation at the site and sought opinions from professional archaeologists as to the best way to conserve the site. Through a Preservation Trust Fund Grant from the Texas Historical Commission, funds were acquired for conservation. The foundation first wished to protect and preserve the kilns with a plastic dome, but more appropriate archaeological solution was chosen, in which the kilns were documented and backfilled. In 1985 a State of 
Texas Historical Marker was set up and now stands in front of the Capote Baptist Church on FM 466 to honor the Wilson Pottery Businesses. The cemetery and school are also located next to the church and stand as important indicators of this time in history. Now the Wilson-DurhamChandler site, located only two miles away from the church, school, and cemetery, will serve as yet another marker of these accomplishments.

During the Wilson reunions, family members visit the site. They walk the land and observe the kilns where their ancestors fired stoneware pottery. They fit their hands into the finger molds where their ancestors squeezed clay to make kiln furniture. The landscape of the Wilson-DurhamChandler site embodies the social memory of some of the first freedmen entrepreneurs in Texas. The connection to this place offers a physical connection between the modern Wilson family members and their cultural heritage.

Lastly, the Wilson Pottery Foundation also works to disseminate this historical knowledge at events in Seguin and across Texas. The Wilson Antique Pottery Collectors Show, previously called the Texas Collector's Pottery Show, has been put on in October of every year since 2003. Sponsored by the Wilson Pottery Foundation, this show brings together antiques collectors from across Texas to exchange pottery and information on antique pottery, and helps the foundation seek additional Wilson pieces. The Wilson pottery is currently on exhibit at the Bob Bullock State History Museum in Austin, and was also celebrated at an exhibit at the Bayou Bend Collections and Garden in Houston, in an exhibit entitled "The Wilson Potters: An African-American Enterprise in 19th Century Texas" in 2002. Several Wilson pots are still on exhibit in the museum. In a final example, a permanent exhibit at the Institute of Texas Cultures of the University of Texas, San Antonio highlights the contribution of the Wilson Pottery to Texas history in their African American Texans section. There, an exhibit called "Early Entrepreneurs in Texas" provides information on stoneware pottery technology, the John McKamie Wilson site (41GU6), as well as an overview of the Wilson family history. Staff archaeologist Shirley Mock worked with the Wilson Pottery Foundation to put together the exhibit. The story of John McKamie Wilson and Hiram Wilson and the establishment of the pottery is a key part of the information provided.

The 2008 designation of the Wilson-DurhamChandler site (41GU4) as a State Archaeological Landmark not only commemorated past individuals that have helped shaped social relations within Texas, but also served as a public acknowledgement of the way that the Wilson Pottery Foundation is utilizing archaeology toward an active form of identity-building through material links to the past. This work continues with the construction of the Wilson Pottery Museum in Seguin.

\section{The Future of the Wilson Pottery Sites}

The major development to come in the future of the Wilson Pottery Sites is the establishment of the museum in Seguin. The Wilson Pottery Foundation is working with the help of the city of Seguin to convert a former residence near the center of town into a functional museum to house Wilson Pottery and other material remains, and to provide a place to educate the public on the accomplishments of the Wilson ancestors.

At the time of this publication, there have been many positive steps toward the establishment 
of the museum, although much still remains to be accomplished. The city has agreed to lease the building to the Wilson Pottery Foundation basically free of charge. They have also offered funds to refurbish the building, which is a substantial in-kind donation since the location needed significant clean-up work. However, this museum needs more than a simple building to house the materials. The importance of the Wilson Pottery subject matter to the history of African American, Texans, and the United States in general warrants a large-scale museum complex, complete with administrative offices, curation facilities, gift shop, and café. It is this type of museum that generally succeeds in attracting visitors to small towns such as Seguin. For this reason, the Texas Historical Commission is working with a museum designer and architect to come up with plans that will meet these specific needs of the Wilson Pottery Museum. This work is underway at the time of this publication and is starting by focusing on drawing up plans, adjusting the project budget, and fundraising.

The 41GU4 site itself will continue to be maintained by the Wilson Pottery Foundation as a place where their family members can enjoy the landscape and cultural remains of the WilsonDurham-Chandler Pottery site. It is their intention to continue to conduct tours and presentations at the site and educate younger generations of the Wilson family about the significant contributions that their ancestors made to the United States following the Civil War. The Wilson Pottery Foundation also hopes to put up a structure where pottery making demonstrations can be conducted and school groups can meet for lectures, as well as an information center, permanent restrooms, and a picnic area. The foundation plans to offer tours to public groups, although the site will remain fenced and locked as they continue to protect this piece of cultural heritage. The other two Wilson
Pottery sites are still under the control of private landowners.

Through this work of the Wilson Pottery Foundation, the Wilson-Durham-Chandler site is now protected. Its material remains are being used to exhibit pride in important individuals and events of the past, as well as educate others on these significant pieces of history. Ongoing work by the individuals involved in this project will continue toward these goals in upcoming years, and I look forward to witnessing the exhibition of these materials in the Wilson Pottery Museum. 


\section{References Cited}

Andrews, Jean

2008 Handbook of Texas Online, http://www.tshaonline.org/handbook/online/articles/WW/fwibf. html (accessed April, 2009).

Blake, Marie E., Steve Johnson, and Richard Kinz

1999 Firing up the Kilns: An archaeological study of three 19th century potteries in Guadalupe County has unearthed new information about some of the first Aftican-American businesses in the state. Heritage 17(4):20-24.

Brackner, Elmer Joe, Jr.

1981 The Wilson Potteries. Masters' Thesis, University of Texas at Austin.

Britt, LaVerne Lewis

2005 In Praise of Hiram Wilson: The Story of a 19th Century Guadalupe County Potter. Xlibris Corporation, Bloomington, Indiana.

Brown, Michael K.

2002 The Wilson Potters: An African-American Enterprise in 19th Century Texas. Bayou Bend Collection and Gardens, The Museum of Fine Arts, Houston.

Greer, Georgeanna H.

n.d.a. Stoneware in Texas. Manuscript on file at the Center for Archaeological Research, the University of Texas, San Antonio.

n.d.b. Texas Pottery. Manuscript on file at the Center for Archaeological Research, the University of Texas, San Antonio.

1981 American Stonewares, The Art and Craft of Utilitarian Potters. Shiffer Publishing Limited, Exton.

1985 Nineteenth Century Potteries in Texas. Manuscript on file at the Center for Archaeological Research, the University of Texas, San Antonio.

Humphreys, Sherry B. and Johnell L. Schmidt

1976 Texas Pottery. Star of the Republic Museum, Washington, Texas.

Montgomery, Le Juene Embry

2004 A Day in the Life of a Wilson Potter: A Brief Account of Texas Utilitarian Pottery in the Late 1800 's. Wilson Pottery Foundation, San Antonio. 
